\title{
Geotechnical Appraisal of Ile-Oluji Federal Polytechnic Using Geographical Information System (GIS)
}

\author{
Olumuyiwa Samson Aderinola, Ajibola Ibrahim Quadri \\ Civil Engineering Department, The Federal University of Technology, Akure, Nigeria \\ Email: osaderinola@futa.edu.ng, aiquadri@futa.edu.ng
}

How to cite this paper: Aderinola, O.S. and Quadri, A.I. (2018) Geotechnical Appraisal of Ile-Oluji Federal Polytechnic Using Geographical Information System (GIS). Open Access Library Journal, 5: e4972.

https://doi.org/10.4236/oalib.1104972

Received: October 9, 2018

Accepted: October 28, 2018

Published: October 31, 2018

Copyright $\odot 2018$ by authors and Open Access Library Inc.

This work is licensed under the Creative Commons Attribution International License (CC BY 4.0).

http://creativecommons.org/licenses/by/4.0/

\begin{abstract}
The use of Geographic Information System has been a good solution for database management due to the fact that Geographical information system has the ability to store, manipulate, analyze and display graphical information that has been referenced to a location on the earth. With the aid of Geographic Information System, the research was able to produce a map showing the AASHTO soil classification system, plastic limit, shrinkage limit plasticity index, percentage fine, percentage sand, percentage gravel, specific gravity, optimum moisture content, elevation and maximum dry density on a thematic map of Federal Polytechnic, Ile-Oluji campus which could be of assistance during the infrastructural development of the institution and also help in producing information which could be of help in the engineering decisions of the institution.
\end{abstract}

\section{Subject Areas \\ Civil Engineering}

\section{Keywords}

GIS, Thematic Map, Soil Classification, Artterberg limit, Elevation and Maximum Dry Density

\section{Introduction}

Soil is an essential component in civil engineering infrastructural development. It often controls the design and cost of construction projects, predominantly lightweight and shallow founded structures [1]. Soil is a natural material having variety of physical properties, most of which vary from place to place. Index 
properties of soils are those properties which are mainly used in the identification and classification of soils and aid the geotechnical Engineer in predicting the suitability of soils as foundation/construction material [2]. Soil surveys are now being adapted in digitally through Global Information System (GIS) technology [3].

GIS has shown very important role in various aspects of geotechnical engineering; preliminary site investigations, identification of potential project barriers (like mines etc), interpolation for obtaining data at inaccessible locations, data visualization, data processing as well as preparation of post processing graphs and charts. Hence GIS finds its applications at all the stages of a geotechnical engineering project [4]. An integrated Geographic Information System and knowledge based Geostatistical system developed by [5] enables to view and retrieve the subsurface data. With government and investors conducting numerous construction projects, the amount of documentation needing to be stored quickly becomes overwhelming.

Much of this data is generated from geotechnical investigations and contains soil information as well as its location on earth. The engineering profession quickly identified a need to improve document storage techniques. With the increase in computing power in recent years, most organizations have begun storing past engineering data on computers [6].

The Global Positioning System is a tool used to collect data for Geographic Information System. It is a system of satellites, ground stations and receivers that allows user to find the exact location points on earth [7].

This study focuses on how a geographical information system (GIS) can be used as a search tool for the geotechnical investigation of soil in the Federal Polytechnic, Ile Oluji, Ondo State, Nigeria.

\section{Aim and Objectives}

The aim is geared towards using the Geographical Information System as a search-tool for geotechnical soil investigation in the Federal Polytechnic, Ile-Oluji, Ondo State, Nigeria. In bid to achieve this aim, the specific objectives are to:

- Compile and store geo-referenced soil tests reports in a central database that makes test data available for use at when needed.

- Carry out soil investigation by carrying out geotechnical tests on new and interested locations under the study area.

- Generate a model (map) using the Geographical Information system to analyze the obtained geotechnical properties such as Natural moisture content, Optimum moisture content, Particle size distribution, Maximum dry density, Liquid limit, Plastic limit and Plasticity index.

\section{Methodology}

The study area as shown in Figure 1 is located in the south west region within 


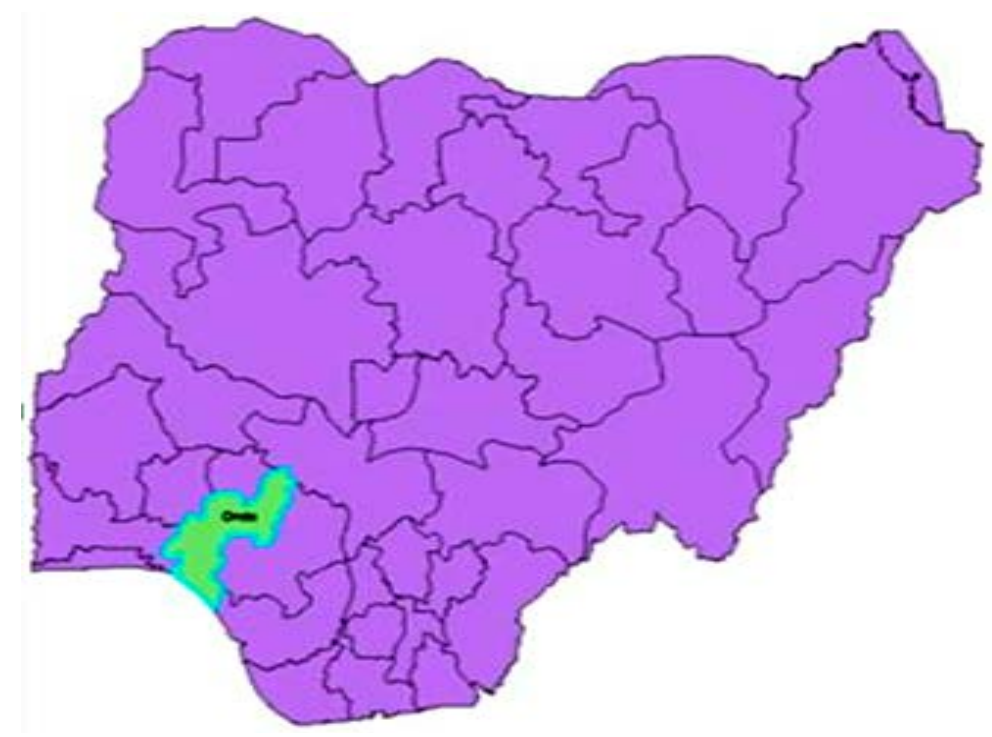

Figure 1. Map of Nigeria showing Ondo state.

the Federal Polytechnic Ile-Oluji, Ile-Oluji, in Ile-Oluji Local Government of Ondo state. The site was undergoing thorough establishment as at the time of carrying out this research. The research was proposed as a recommendation to be adopted for geotechnical prospecting of the area. The study area lies between latitudes $7^{\circ} 14^{\prime} 0 " \mathrm{~N}-7^{\circ} 14^{\prime} 50^{\prime \prime} \mathrm{N}$ and $4^{\circ} 51^{\prime} 0 " \mathrm{E}-4^{\circ} 52^{\prime} 10^{\prime \prime} \mathrm{E}$ covering a land area of $1.53 \mathrm{~km}^{2}$ (Figure 2, Figure 3).

The master plan and geographical map of the institution were obtained and used as base map. The Global Positioning System (GPS) was used to show the exact location (Longitude and Latitude) of areas where samples were collected on the master plan of the area. Undisturbed samples were collected at different locations at depth exceeding $1.5 \mathrm{~m}$ within the study area together with the coordinates of each sample locations. Soil investigations were carried out in other to obtain the geotechnical data and engineering properties of the soil around the location under the study area during the dry season, and as at the planning of establishing building structures on the area. The tests carried out are; Natural moisture content, Specific gravity, Optimum moisture content, Maximum dry density, Particle size distribution, Maximum dry density, Liquid limit, Plastic limit, Plasticity index. The soil samples were classified using the American association of state highway and transportation officials AASHTO classification.

The necessary practical was conducted in the Physical Planning Department and Geotechnical laboratory at the Federal University of Technology, Akure (FUTA). Consequently, various results were obtained for the assessed engineering properties of the soil.

\section{Results and Discussions}

\subsection{Natural Moisture Content}

The Natural Moisture Content (NMC) of the tested soil samples within the study 


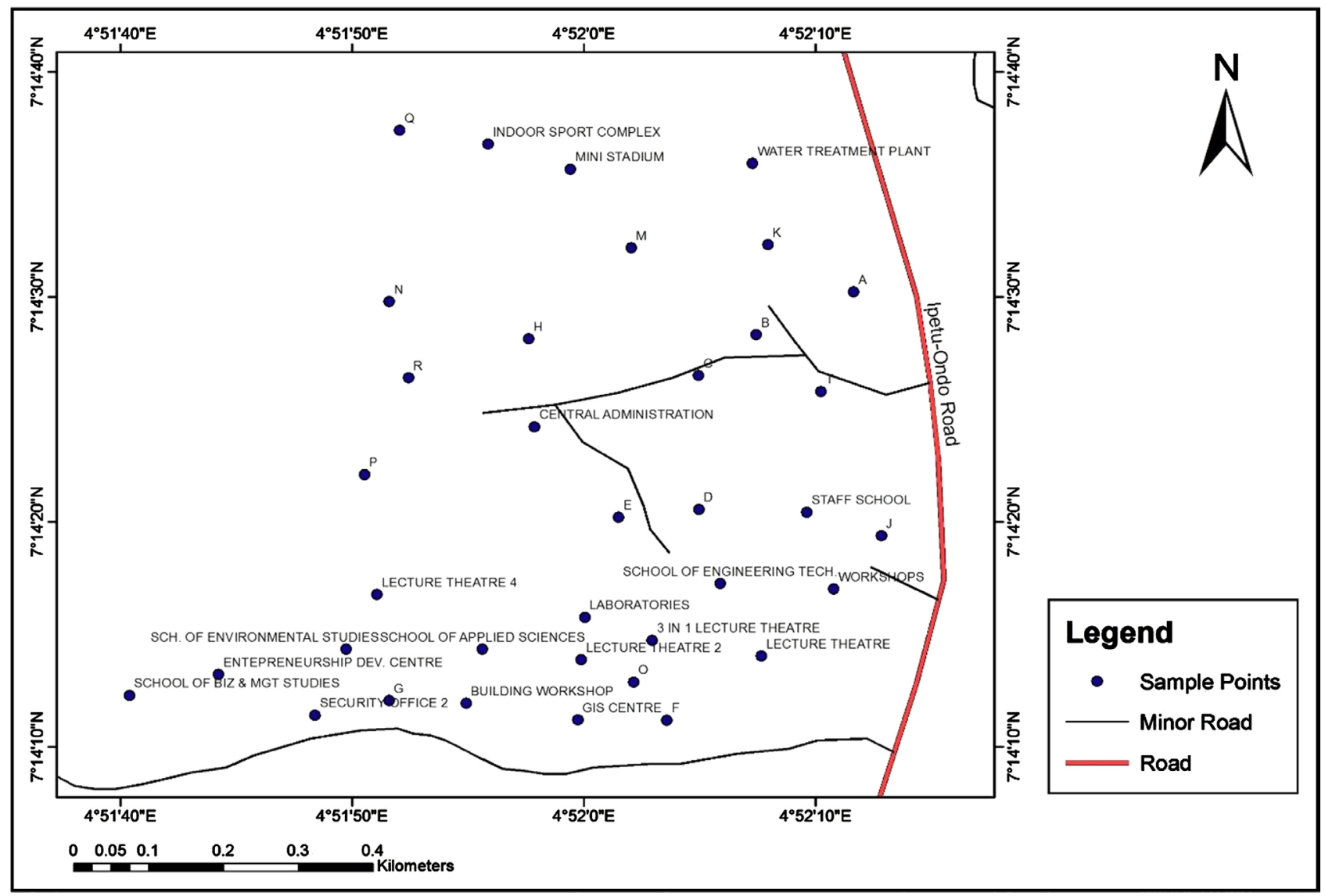

Figure 2. Map of the study area showing the borrowed pits.

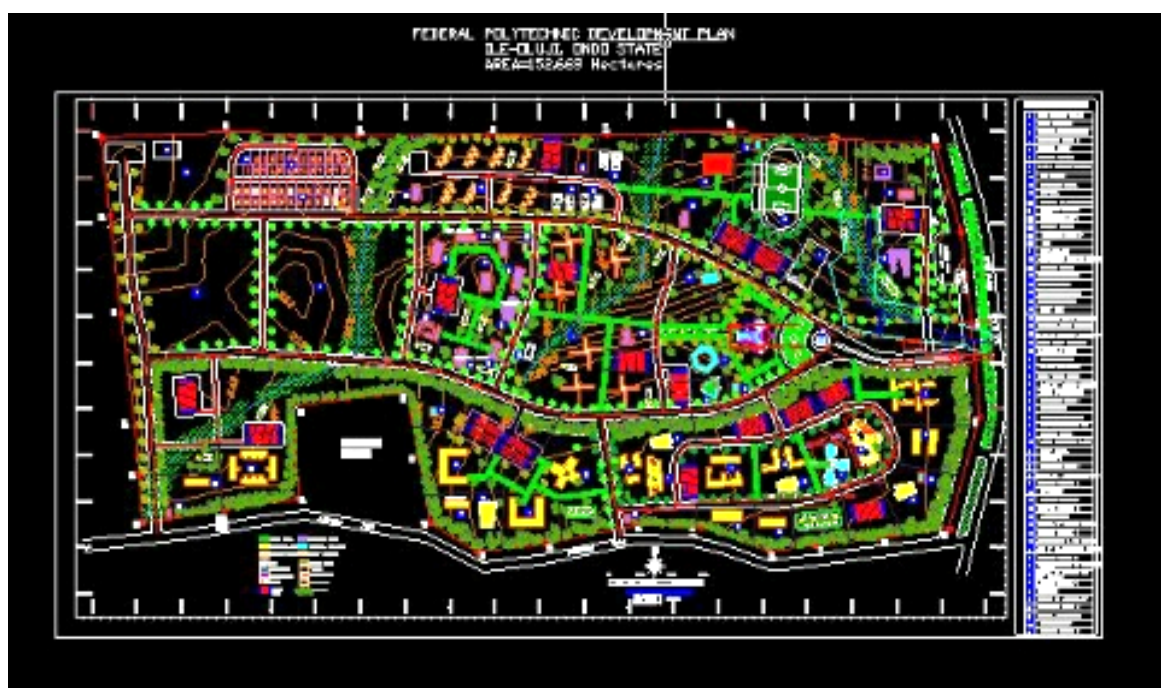

Figure 3. The federal polytechnic, Ile-Oluji plan master.

area is as presented on the contour lines in Figure 4. The NMC ranges between $8 \%$ and $26 \%$ as can be seen around points $\mathrm{D}, \mathrm{H}, \mathrm{O}$ and lecture Theatres 1 and 2 with NMC of 12\%. Contour lines of 14\% join the School of Environmental Studies, School of Applied Sciences, water treatment plants and laboratories, while Lecture Theatre 4 and Central Administration occupy NMC of 16\%. The Staff 
School, Entrepreneurship Development Centre and Security office, Building Workshop, School of Business and Management Studies and the GIS Centre occupy NMCs of $18 \%, 20 \%$ and $22 \%$ respectively. The lowest value of $8 \%$ NMC falls around point $\mathrm{K}, \mathrm{Q}$ and School of Engineering Technology while the highest NMC of $26 \%$ is found around location M. Figure 5 is the thematic map study area. Areas with the same colour have the same range of NMC.

\subsection{Liquid Limit}

Figure 6 shows the Liquid Limit (LL) of the tested samples. The contour lines show the range of LL of $30 \%$ to $40 \%$ around the Water Treatment Plant, School of Business and Management Studies, the GIS Centre and the Indoor Sport Complex. LL ranges between $42 \%$ and $48 \%$ can be seen around the Mini Stadium, School of Applied Sciences, Building Workshop, Laboratories, Security Office, Lecture Theatre 4, Entrepreneurship Development Centre, School of Engineering Technology, and Lectures Theatres 1 and 2. Workshop has the highest LL of $60 \%$. Areas with the same LL are shown with the same colour on the thematic map in Figure 7.

\subsection{Plastic Limit}

The Plastic Limit (PL) of the samples is as presented in Figure 8. Soils with PL ranges between $22 \%$ and $32 \%$ are seen around the Water Treatment Plant, School of Business and Management Studies, Building Workshop, School of Applied Sciences, Indoor Sport Complex, Mini Stadium, and Central Administration. Furthermore, PL ranges between 34\% and 38\% fall around the School of Environmental Studies, Lecture Theatre 4, Laboratories, Security Office, School of Engineering technology, Staff School and Workshop, while the thematic map represents area with the same PL having the same colour see Figure 9.

\subsection{Linear Shrinkage}

The Linear Shrinkage (LS) of the study area is as presented on the contour line in Figure 10. LS between 3\% and 6\% are found around point K, Indoor Sport Complex, Water Treatment Plant, Mini Stadium, School of Engineering Technology, School of Business and Management Studies, School of Applied Sciences while SL between 7\% and 10\% are seen around School of Environmental Studies, Lecture Theatre, Central Administration, GIS Centre Security office, Laboratories, Building Workshop, Entrepreneurship Development Centre, School Office, and Workshop. Figure 11 is the thematic map of the LS, areas with the same SL have the same colour.

\subsection{Plasticity Index}

Areas with Plasticity Index (PI) range from $9 \%$ to $15 \%$ as shown in Figure 12, are around the Water Treatment Plant, Indoor Sport Complex, Mini Stadium, School of Applied Science, School of Business and Management Studies, School 


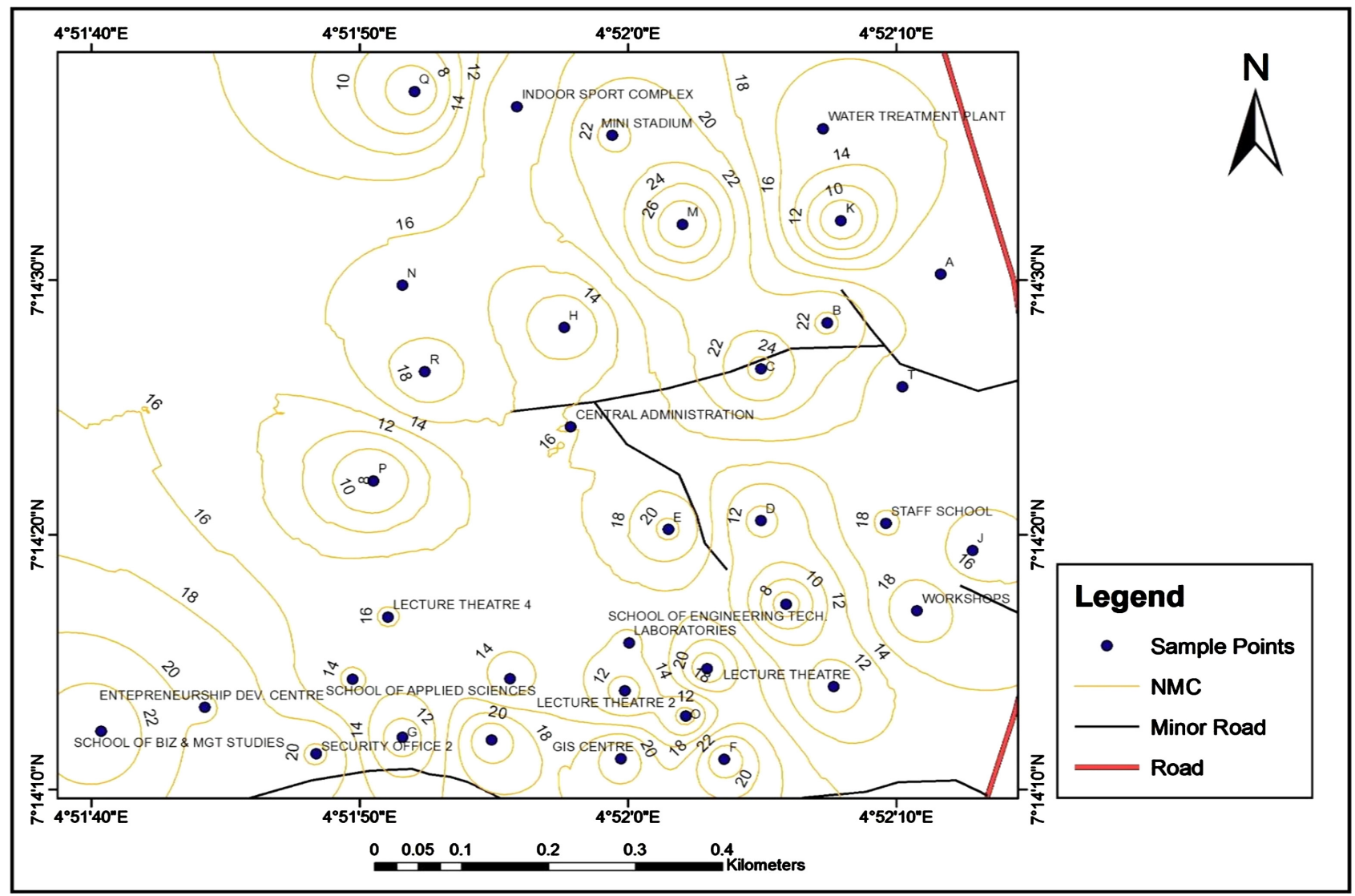

Figure 4. Contour of natural moisture content.

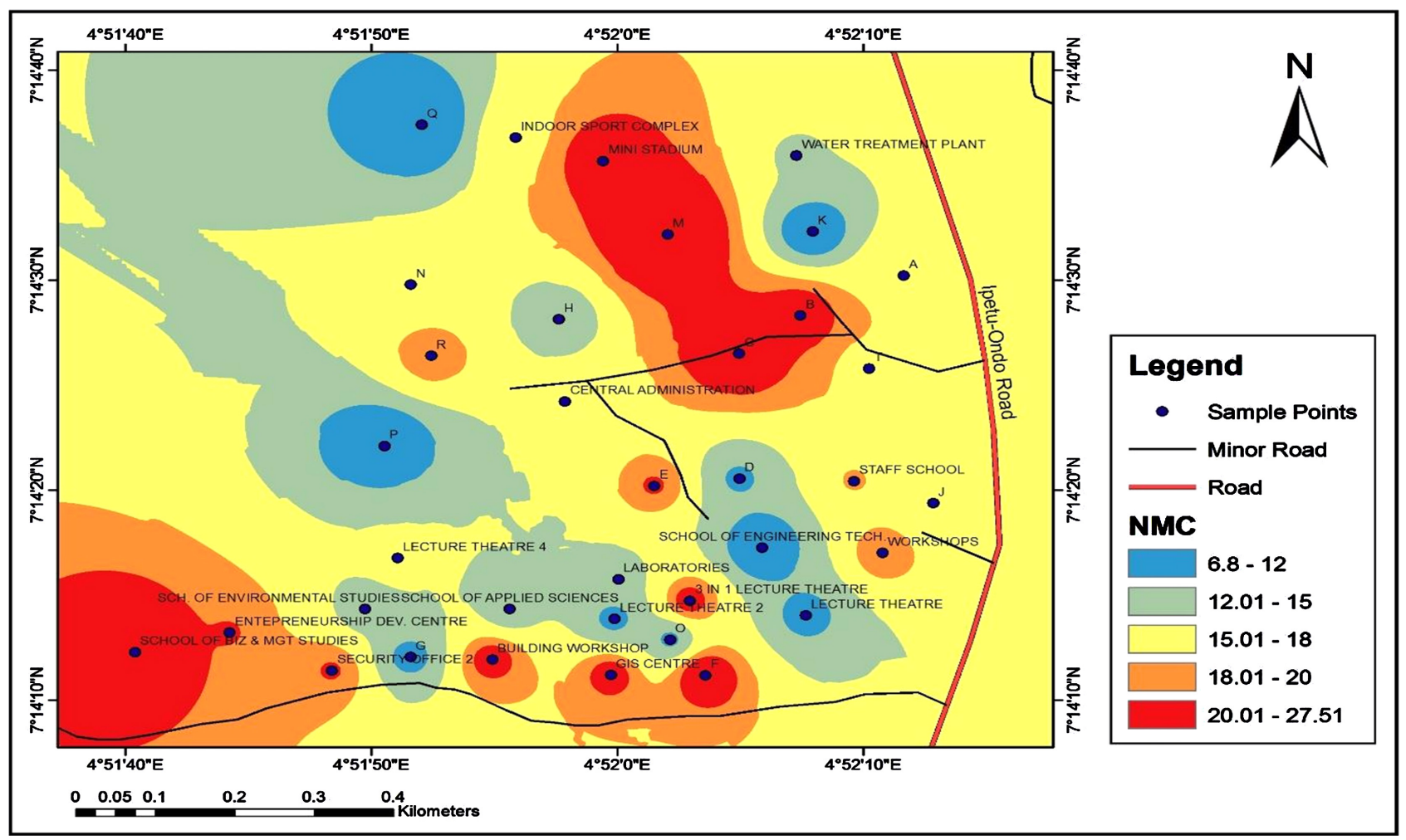

Figure 5. Thematic map of natural moisture content. 


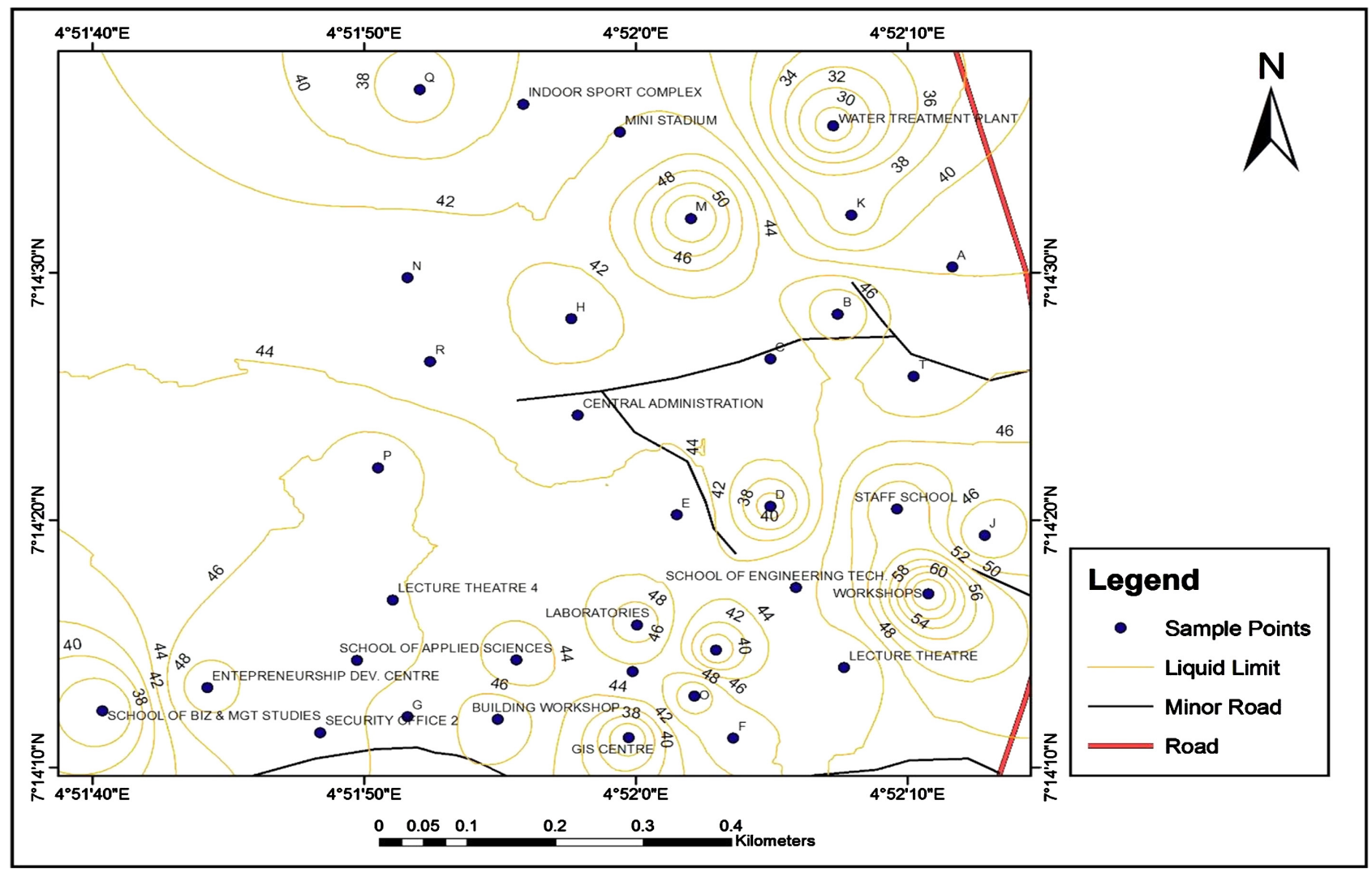

Figure 6. Liquid limit.

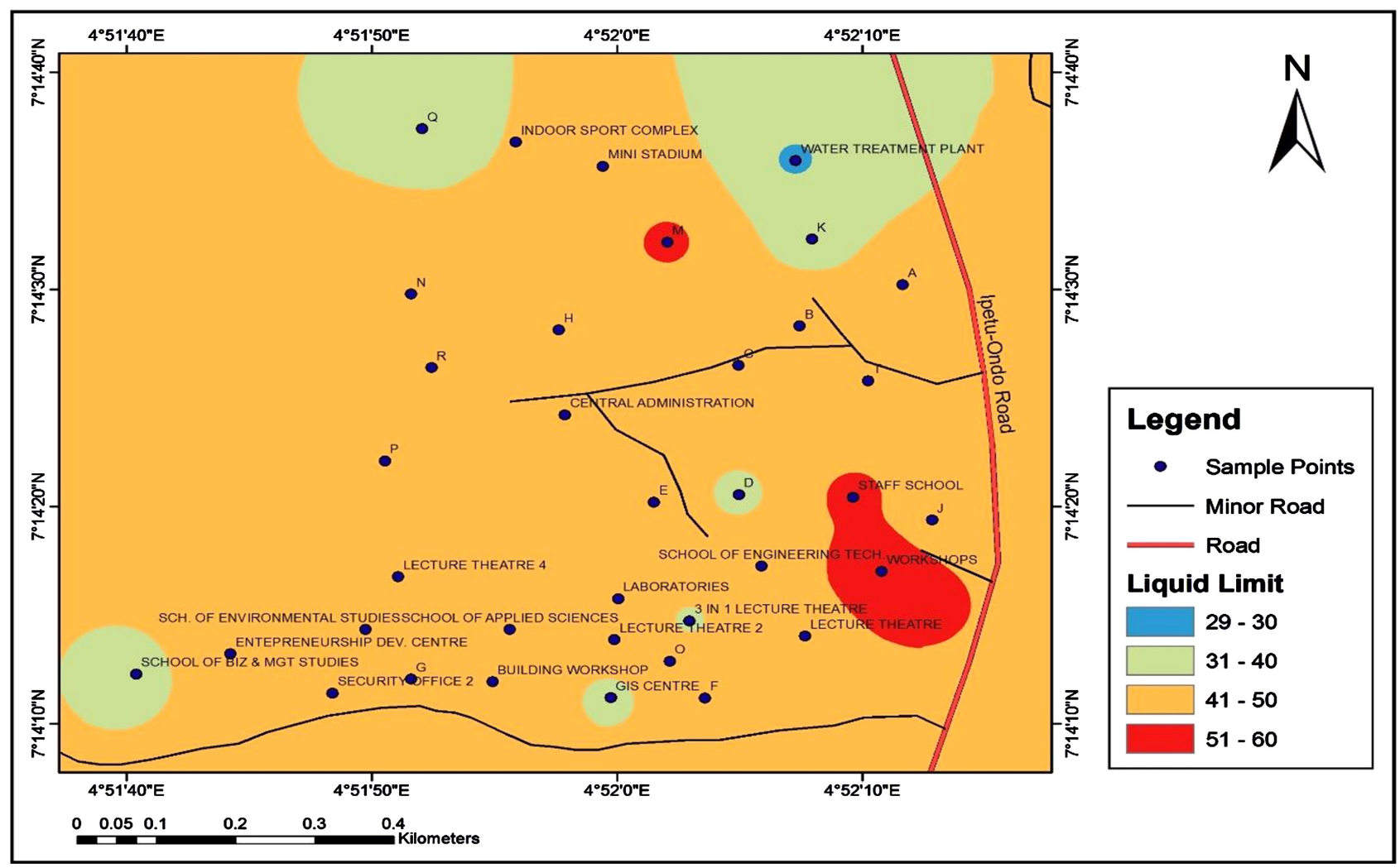

Figure 7. Thematic map of liquid limit. 


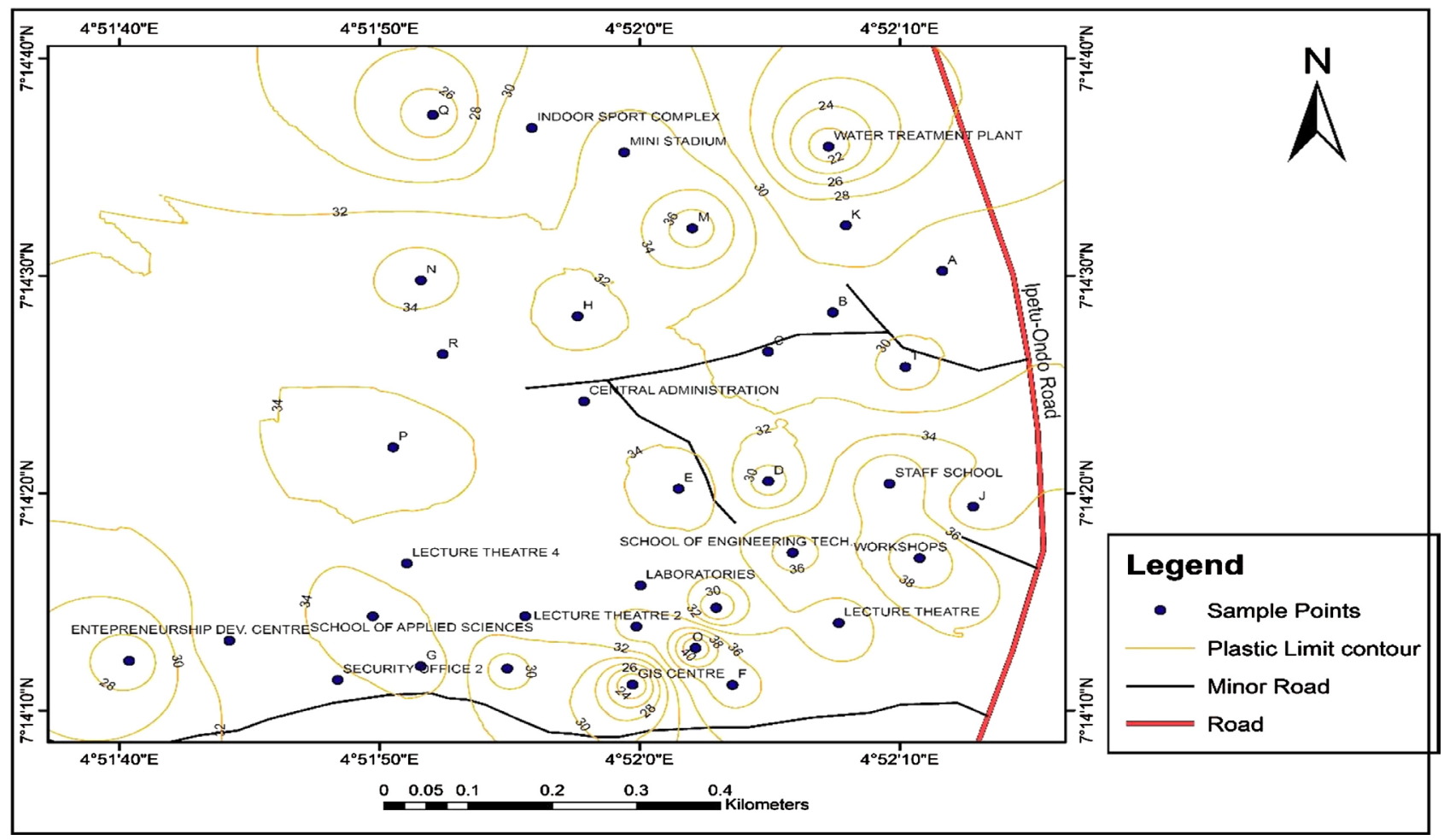

Figure 8. Plastic limit contour.

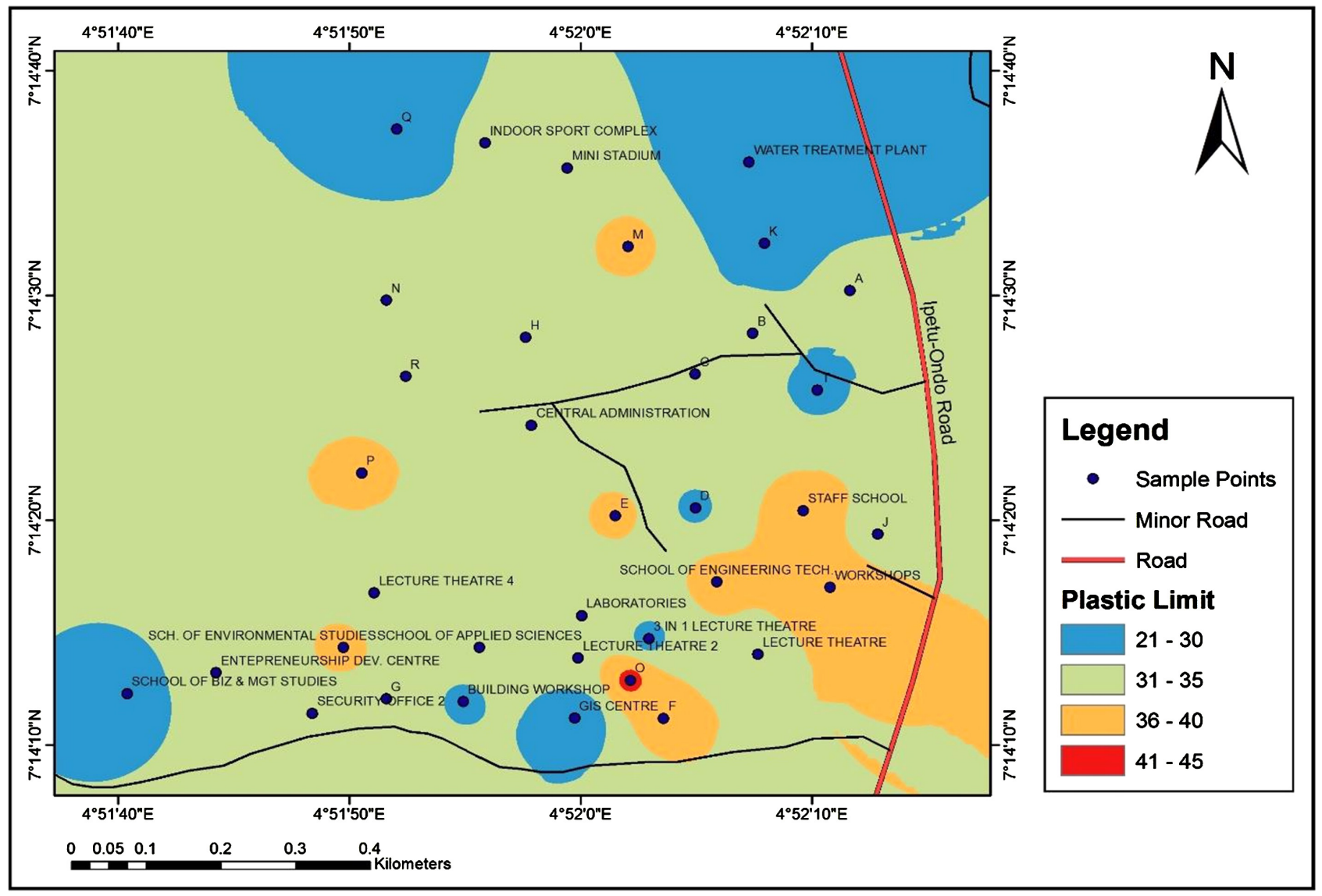

Figure 9. Thematic map of plastic limit. 


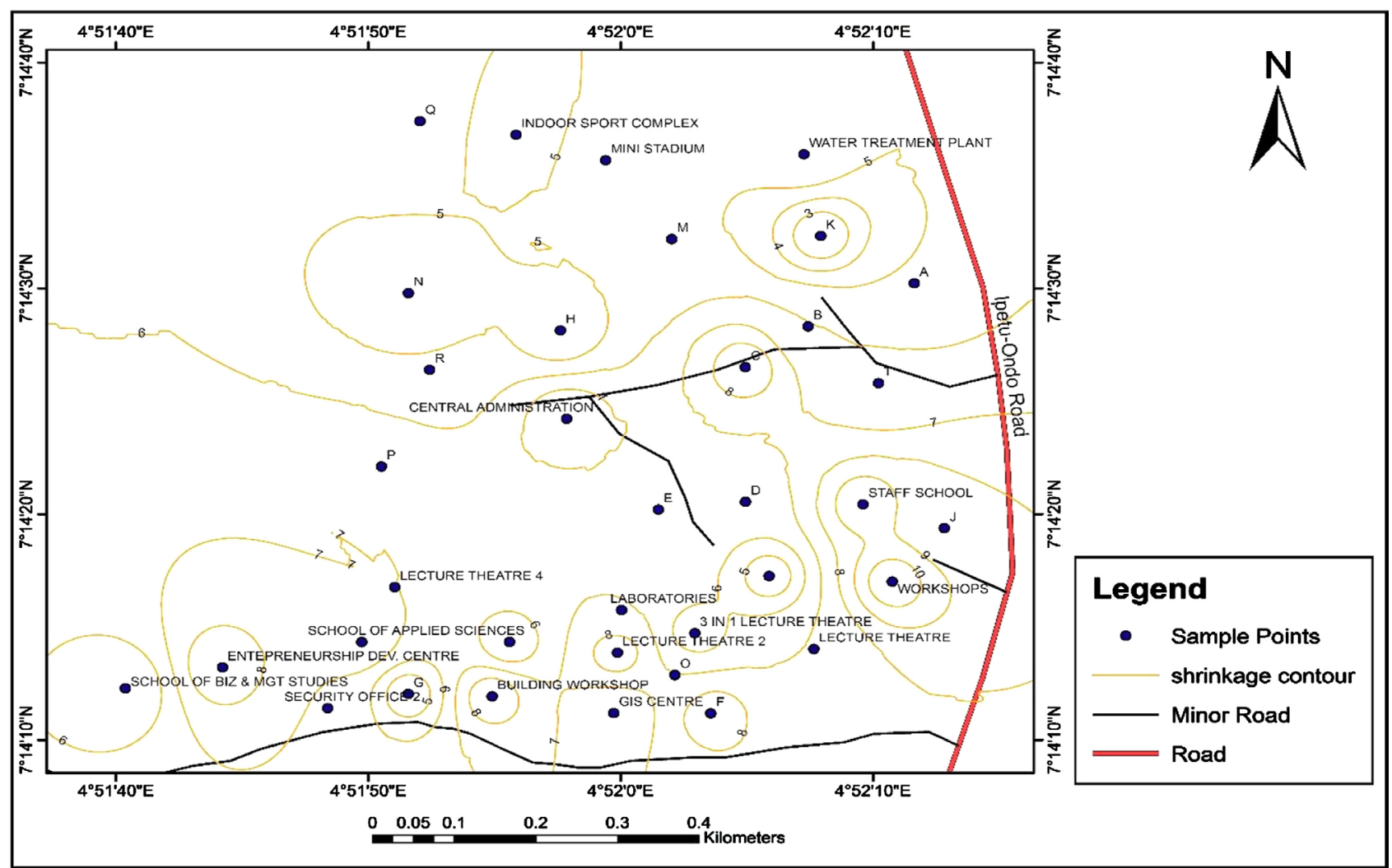

Figure 10. Shrinkage limit contour.

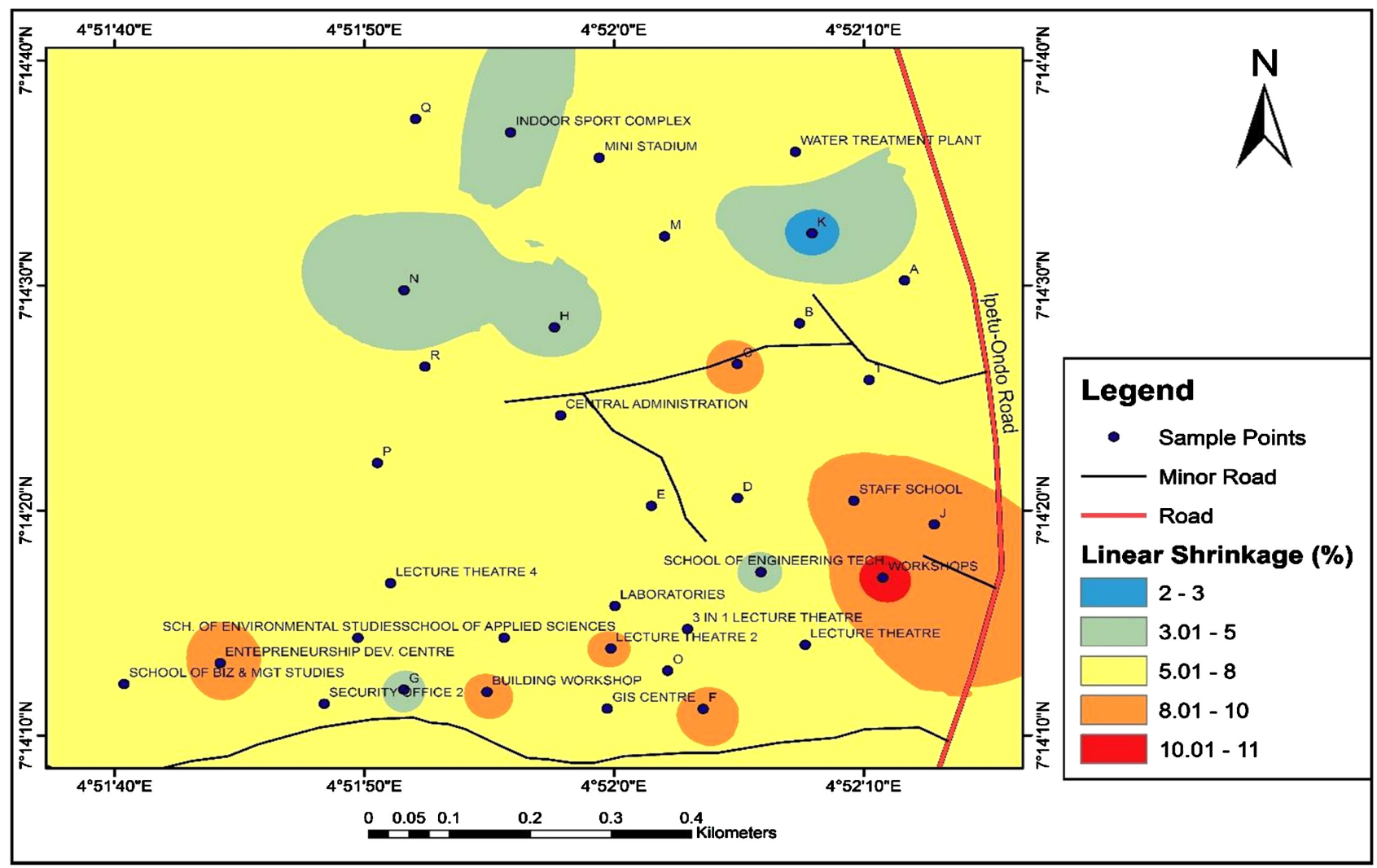

Figure 11. Thematic map of shrinkage limit. 


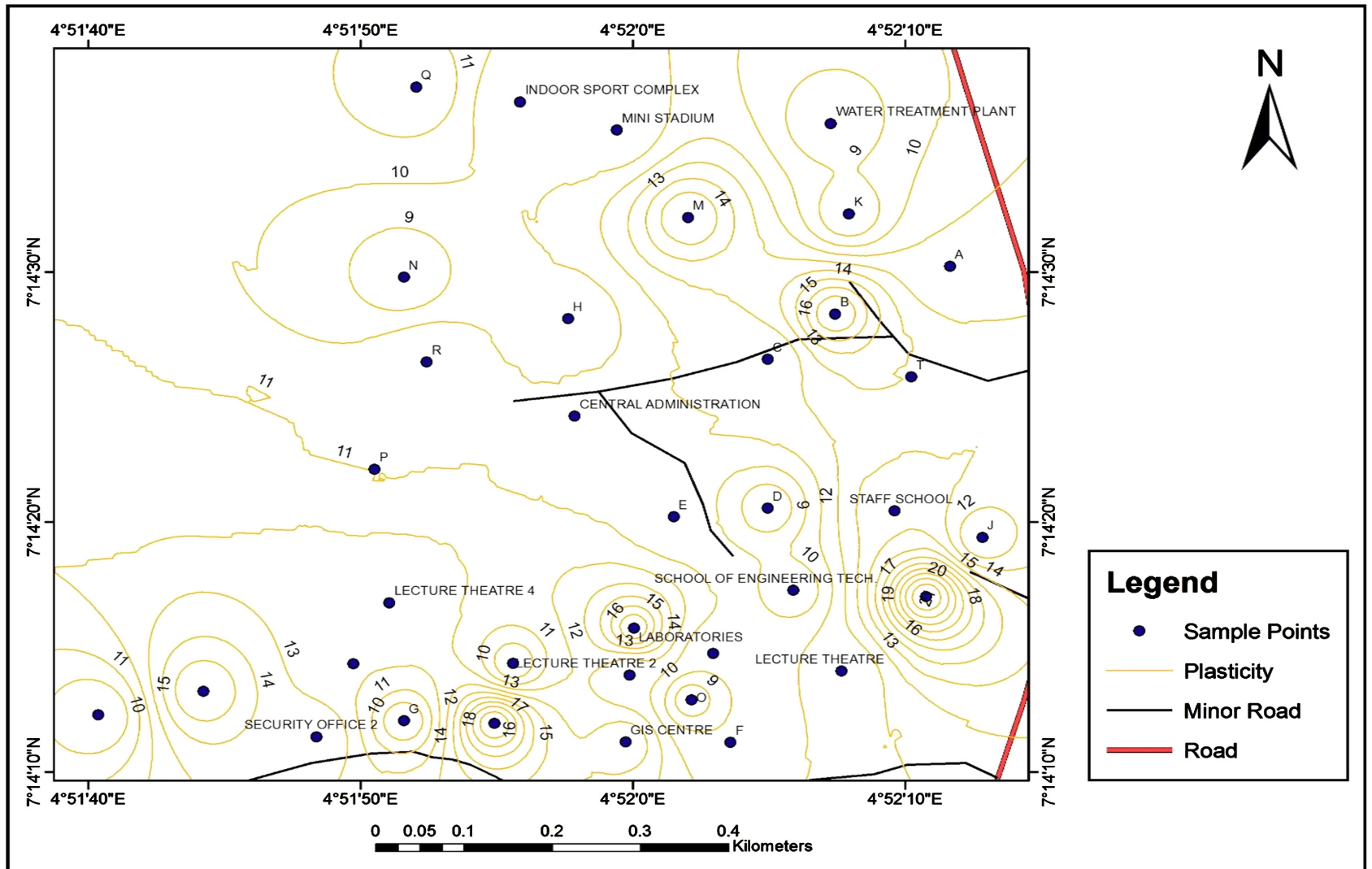

Figure 12. Contour map of plasticity index.

of Engineering Technology, Lecture Theatres 1 and 2, School of Environmental Studies, Staff School, Security Office, and Entrepreneurship Development Centre. PI range between $16 \%$ and $21 \%$ are located around Laboratories and Workshop. Figure 13 is the thematic map of the PI range with the same colour.

\subsection{Percentage Fines}

Figure 14 is the contour lines of the Percentage Fines (PF) present at each location of the study area, while Figure 15 depicts the thematic map of the area with the same Fines. PF ranges between 25 and 40 are located around School of Engineering Technology, School of Applied Science, Entrepreneurship Development Centre, Water Treatment Plant, Lecture Theatre 2, Building Workshop, Laboratories, School of Business and Management Studies and Security Office. While PF range between 45 and 60 are seen around GIS Centre, Staff School, School of Environmental Studies, and Workshop.

\subsection{Percentage Sand}

The Percentage Sand range between 20 and 40 are located around School of Applied Science, Entrepreneurship Development Centre, School of Engineering Technology, School of Business and Management Studies, Central administration, Workshop, Lecture Theatre 4, School of Environmental Studies, Building Workshop and the Security Office as presented on contour lines in Figure 16. 


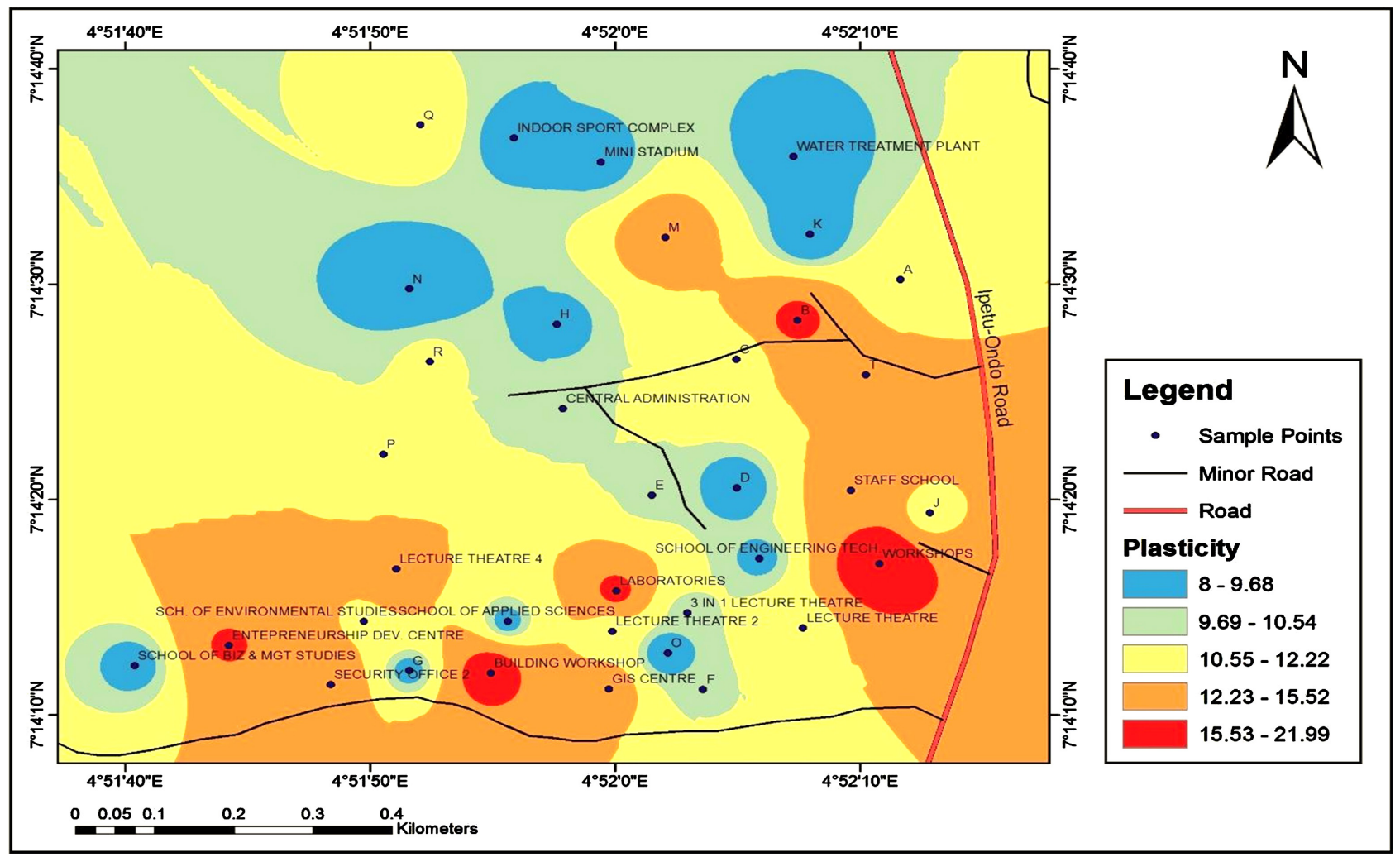

Figure 13. Thematic map of plasticity index.

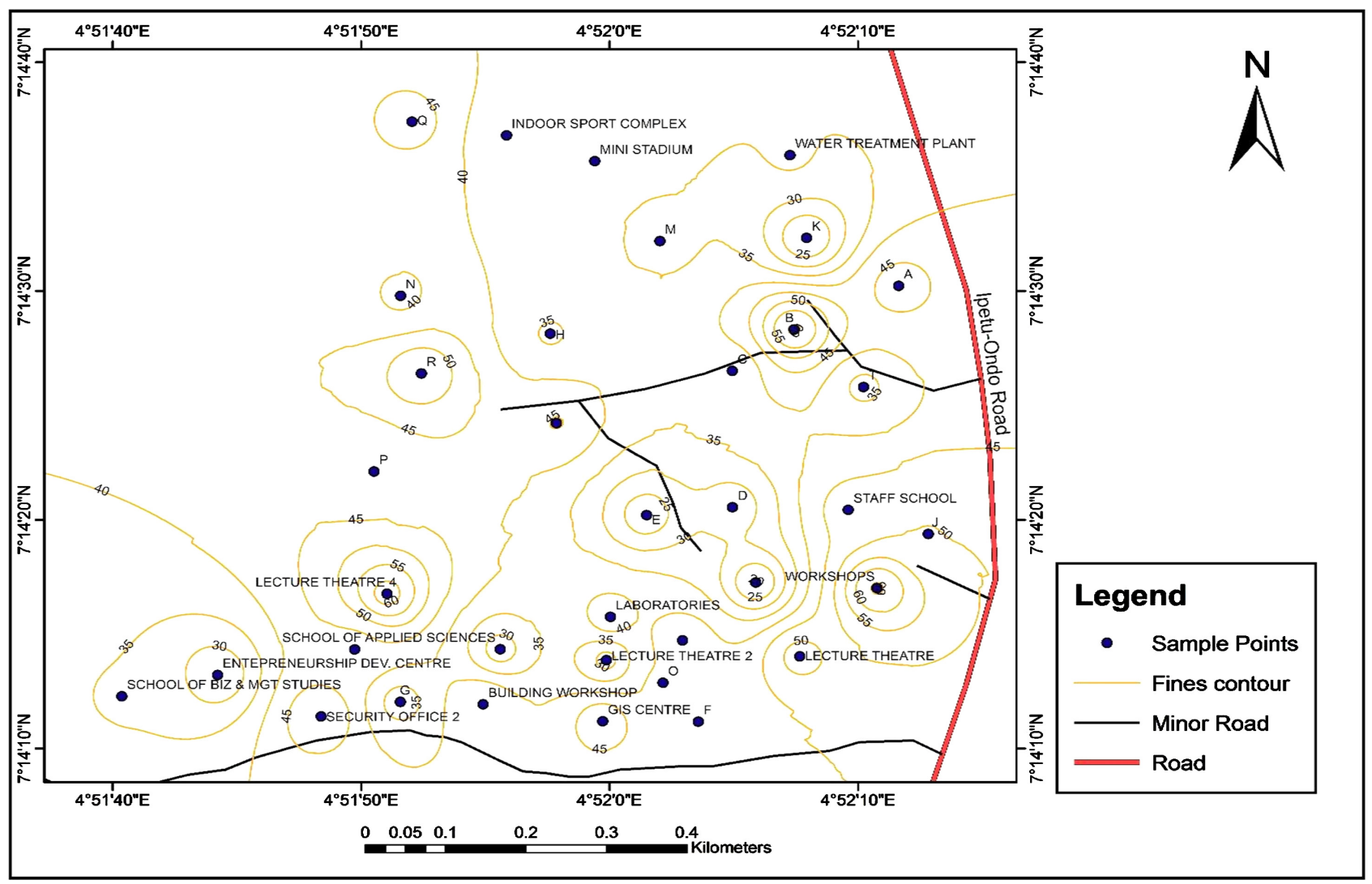

Figure 14. Contour map of \% fines. 


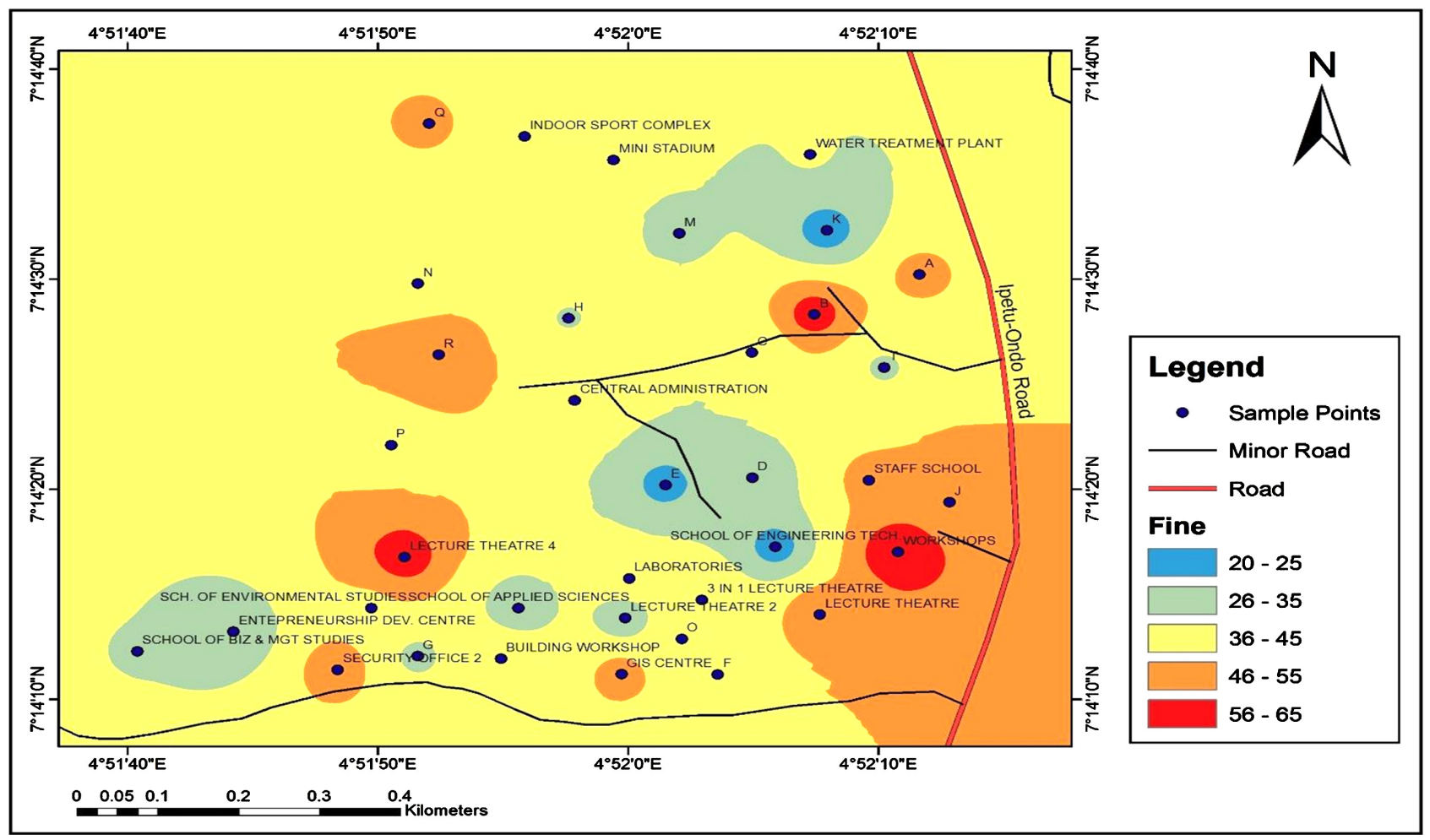

Figure 15. Thematic map of $\%$ fines.

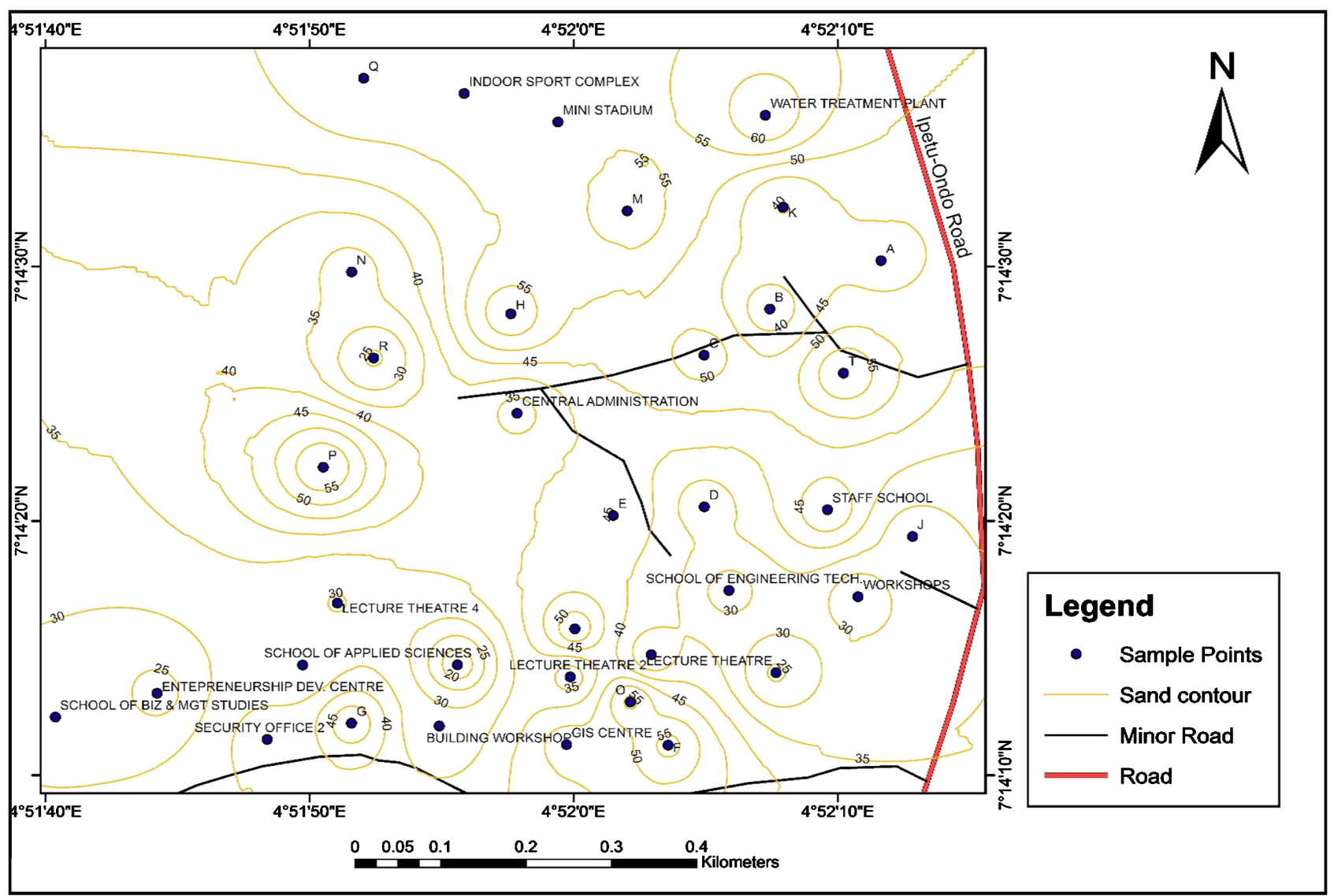

Figure 16. Contour map of $\%$ sand. 
While Percentage Sand range between 45 and 60 are around the GIS Centre, staff School, Indoor sport Complex, Mini Stadium, Laboratories, and Water Treatment Plant. The Percentage Sand thematic map of area with the same percentage is shown in Figure 17.

\subsection{Percentage Gravel}

Figure 18 and Figure 19 are the contour and the thematic map of the study area. Area with Percentage Gravel (PG) range between 5 and 35 are Water Treatment Plant, Workshop, Staff School, GIS Centre, Lecture Theatre 4, Security Office, Indoor Sport Complex, Mini Stadium, School of Environmental Studies, Central Administration, Lecture Theatres 1 and 2, Building Workshop and School of Business and Management Studies. Areas with PG range between 40 and 55 are School of Engineering Technology, School of Applied Science and Entrepreneurship Development Centre.

\subsection{Specific Gravity}

Figure 20 is the contour lines that join areas with the same specific gravity, the highest contour value for the specific gravity is 2.73 as seen around the Lecture Theatre, the lowest contour value for the specific gravity is 2.55 as seen around the Staff School. The specific gravity of soil ranging between 2.5 and 2.69 can be found in Security office, GIS Centre, School of Environmental Studies, School of Applied Sciences, Building Workshop, Lecture theatres1 and 2, Laboratories, Lecture theatre 4, School of Business and Management Studies, Entrepreneurship Development Centre, School of Engineering Technology, Workshops, Staff School, Central Administration, Mini stadium, Water treatment plant, Indoor sport complex. The specific gravity values of 2.5 to 2.67 indicate that sand and silts are predominant, while that of 2.67 to 2.73 shows the presence of clay and silty clay.

\subsection{Optimum Moisture Content}

Figure 21 is the contour lines that join areas with the same Optimum Moisture Content (OMC). Areas with contour value range 12\% to 15\% OMC are seen around the School of Engineering Technology, Central Administration, School of Business Studies, School of Applied Science, Staff School, School Entrepreneurship Development Centre and GIS Centre. Areas with Contour value of 16\% to 20\% OMC range are seen around Lecture Theatres 1 and 2, Security Office, School of Environmental Studies, Mini Stadium, Indoor Sport Complex, Lecture Theatre 4 and Laboratories. From the thematic map Figure 22, areas with the same colour pattern have the same range of natural moisture content.

\subsection{Maximum Dry Density}

Figure 23, shows the contour lines that join areas with the same Maximum Dry Density (MDD) value, Contour lines with MDD value of $1650 \mathrm{Kgm}^{-3}$ joins areas around the Mini Stadium, Workshops Lecture Theatre 2. Contour lines with 


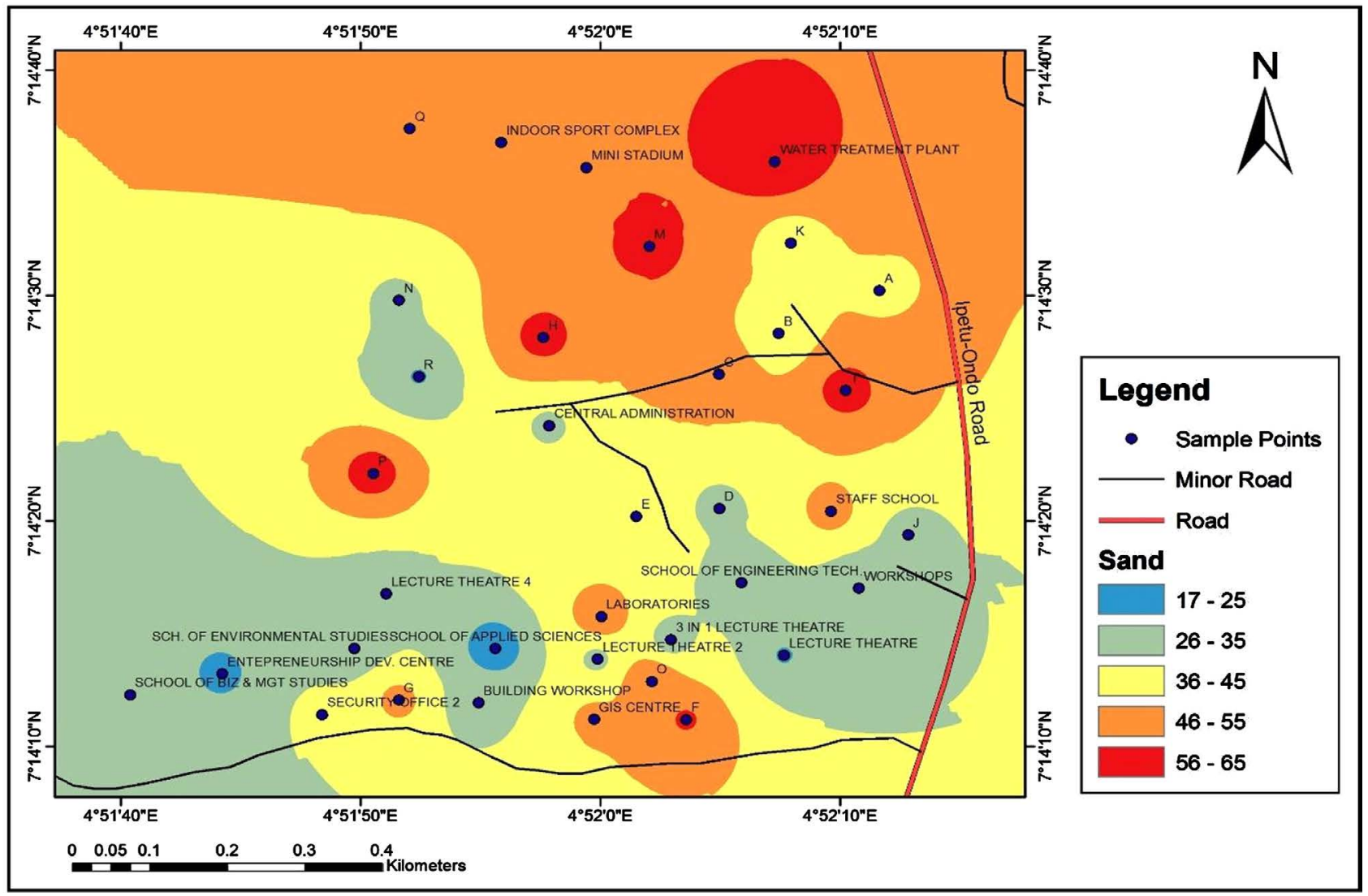

Figure 17. Thematic map of $\%$ sand.

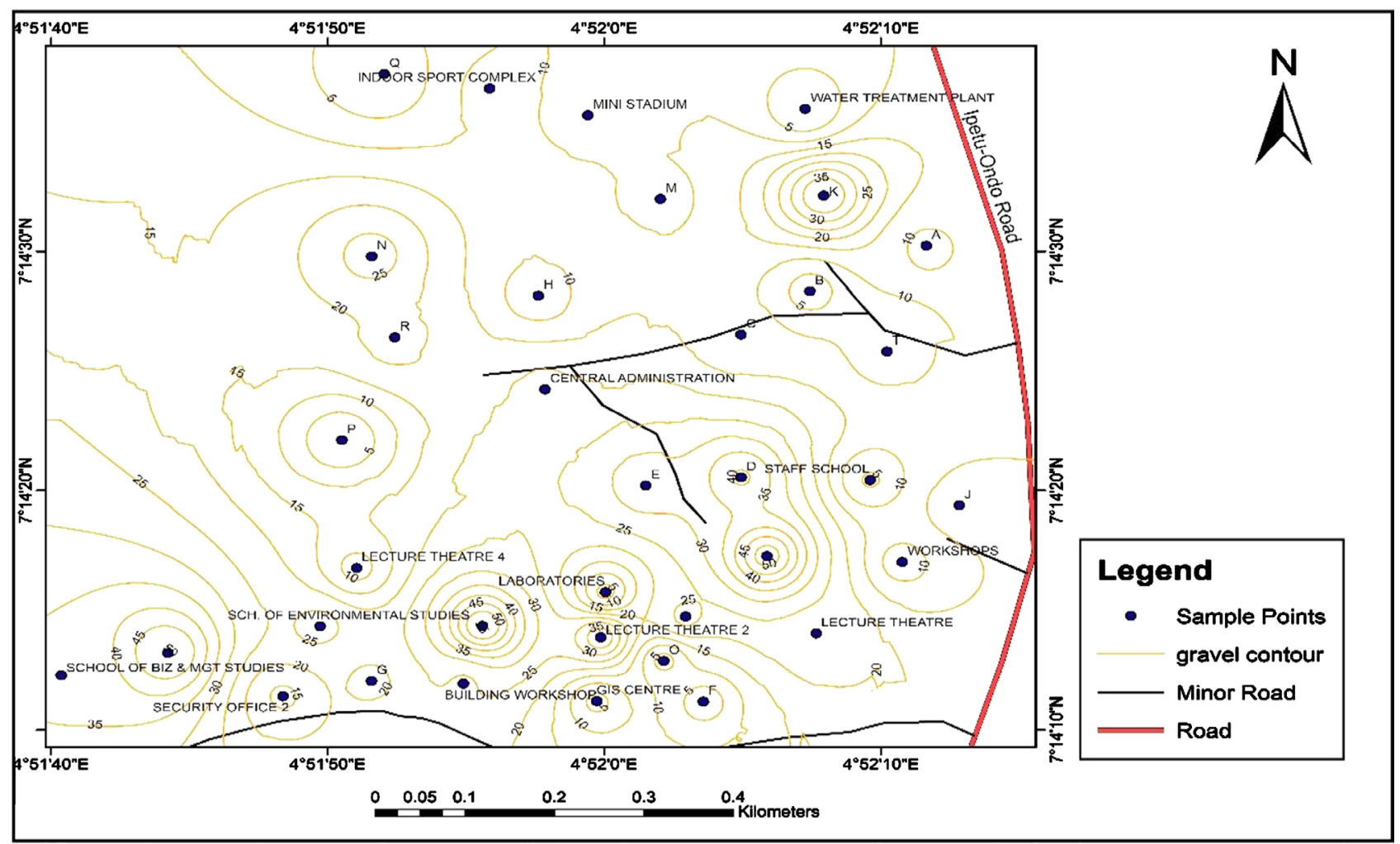

Figure 18. Contour map of $\%$ gravel. 


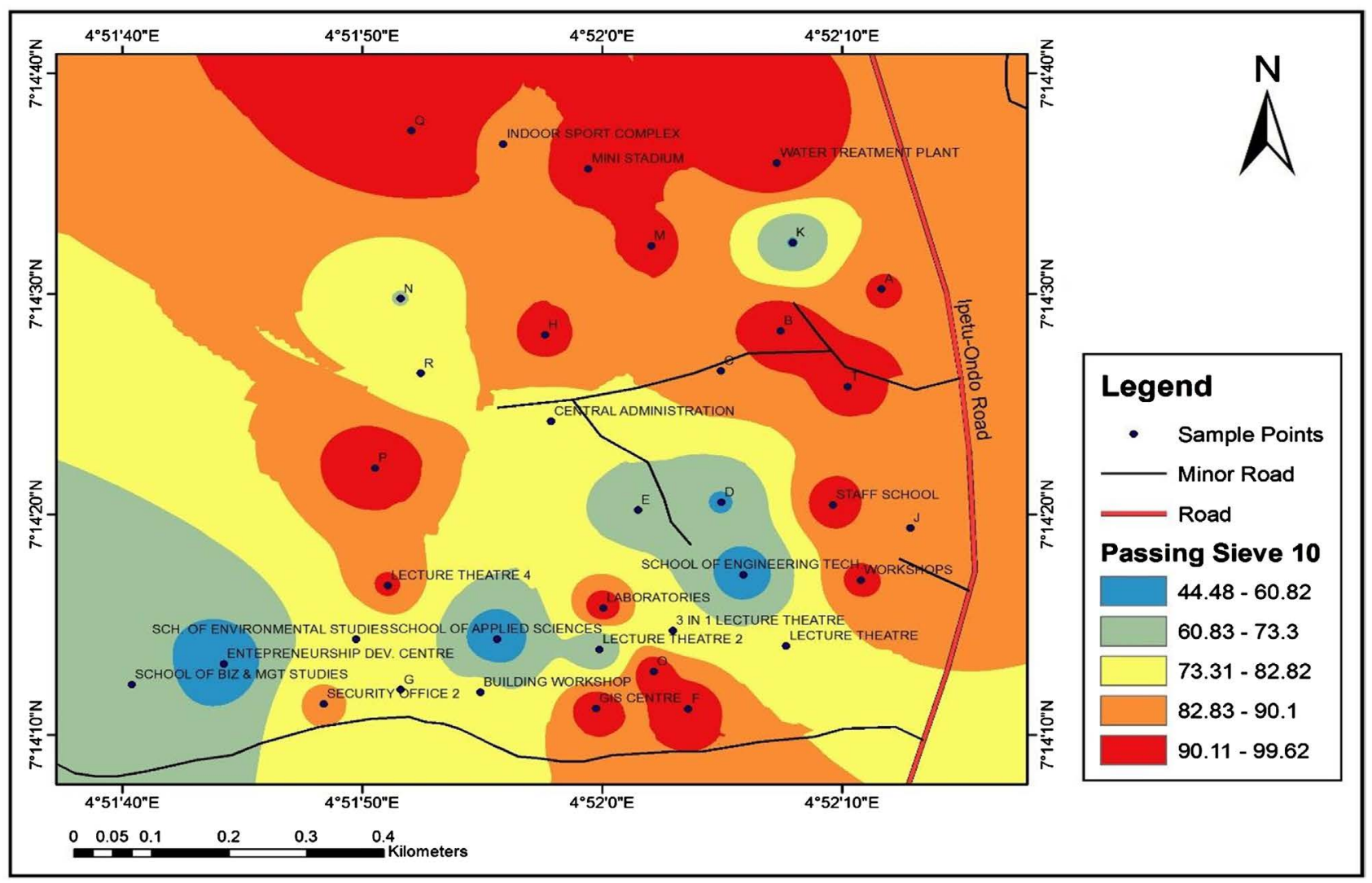

Figure 19. Thematic map of $\%$ gravel.

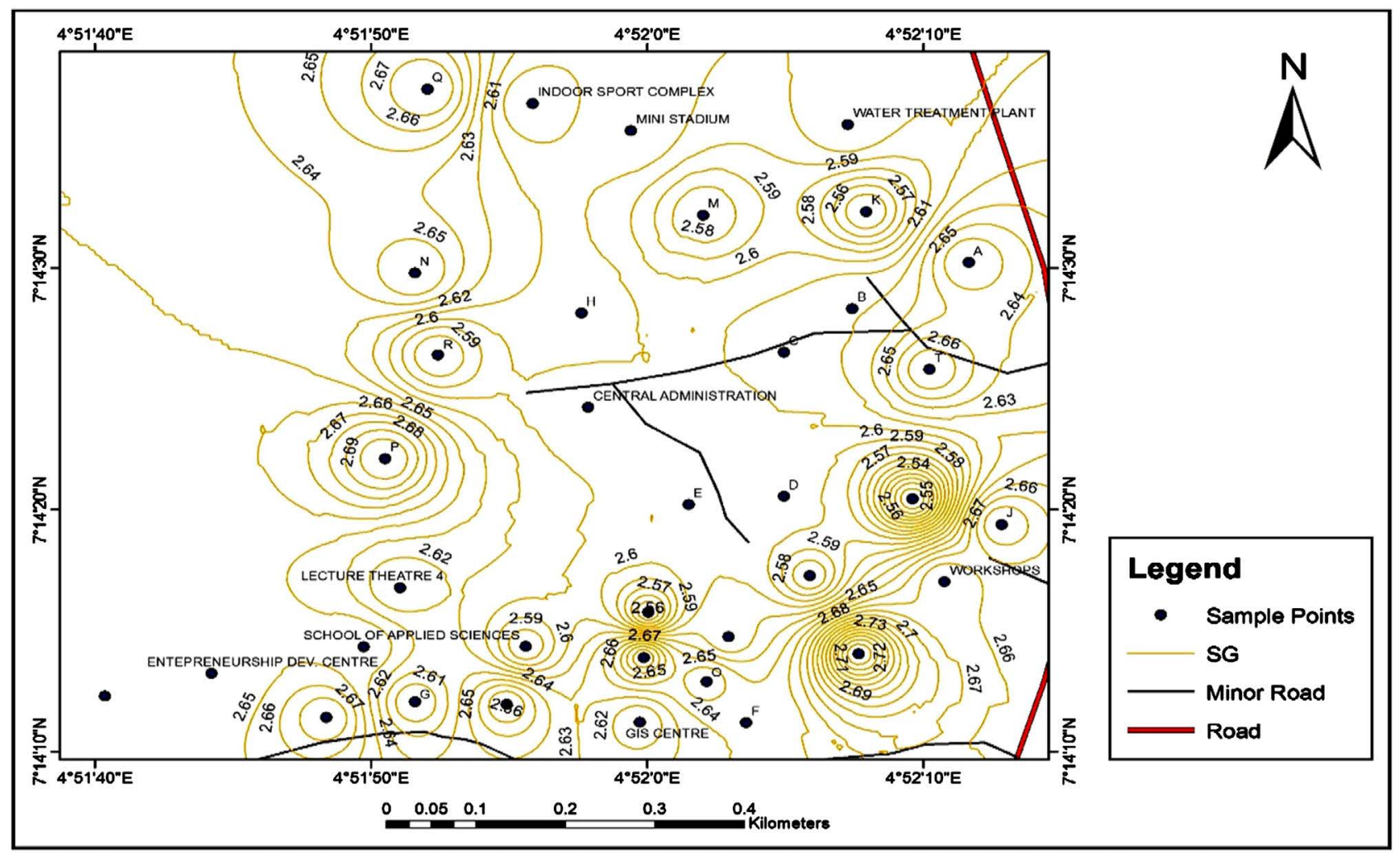

Figure 20. Specific gravity. 


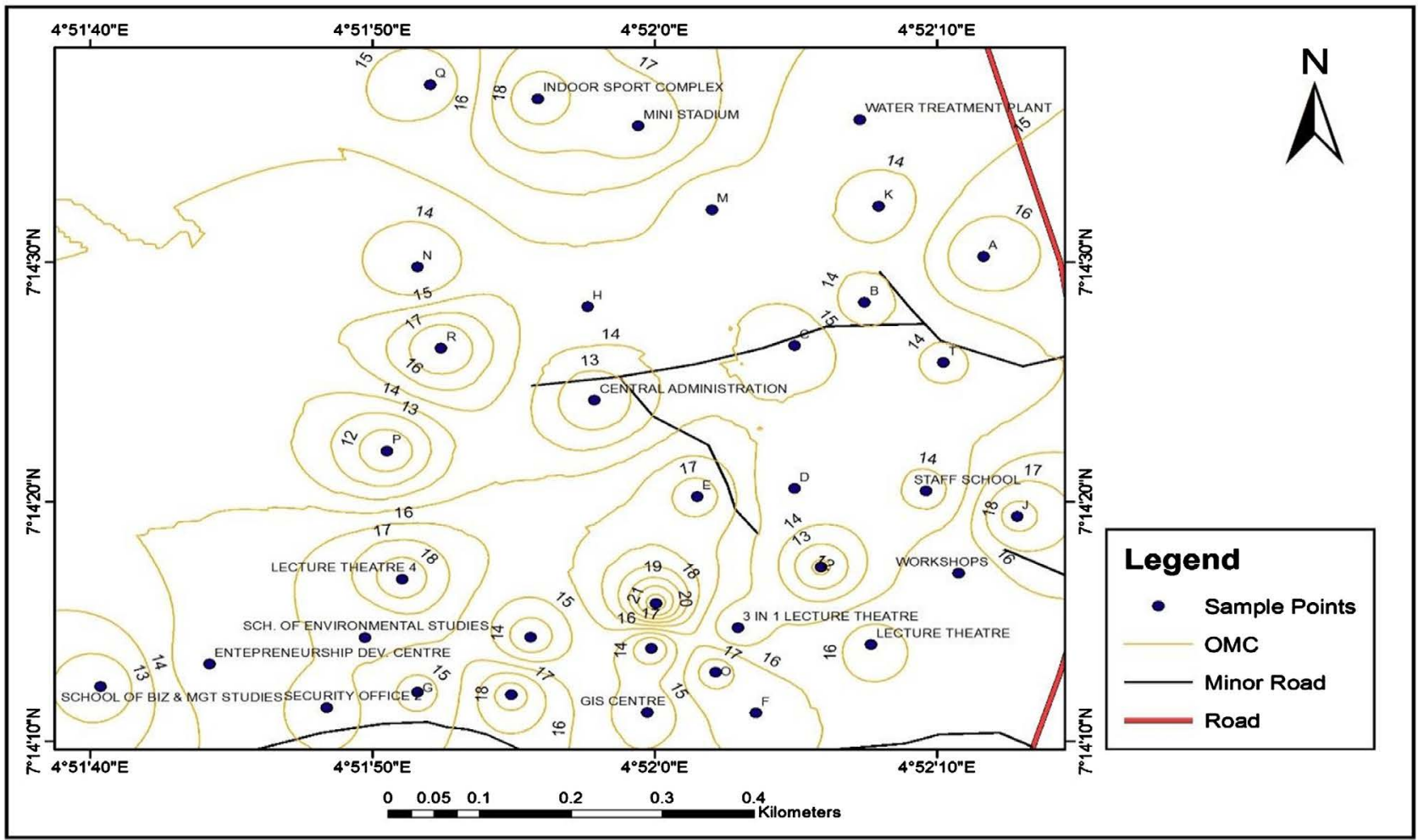

Figure 21. Contour map of optimum moisture content.

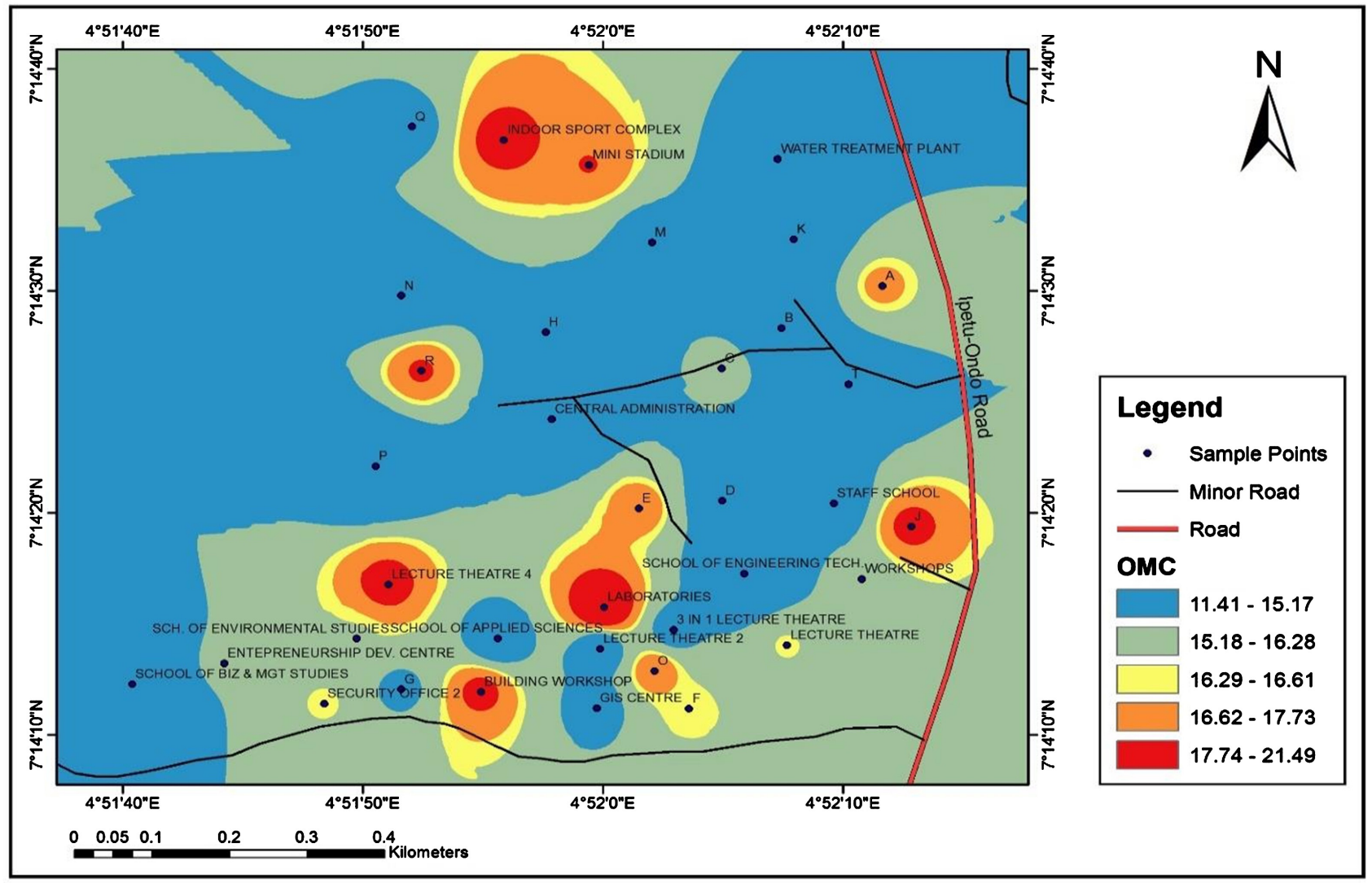

Figure 22. Thematic map of optimum moisture content. 


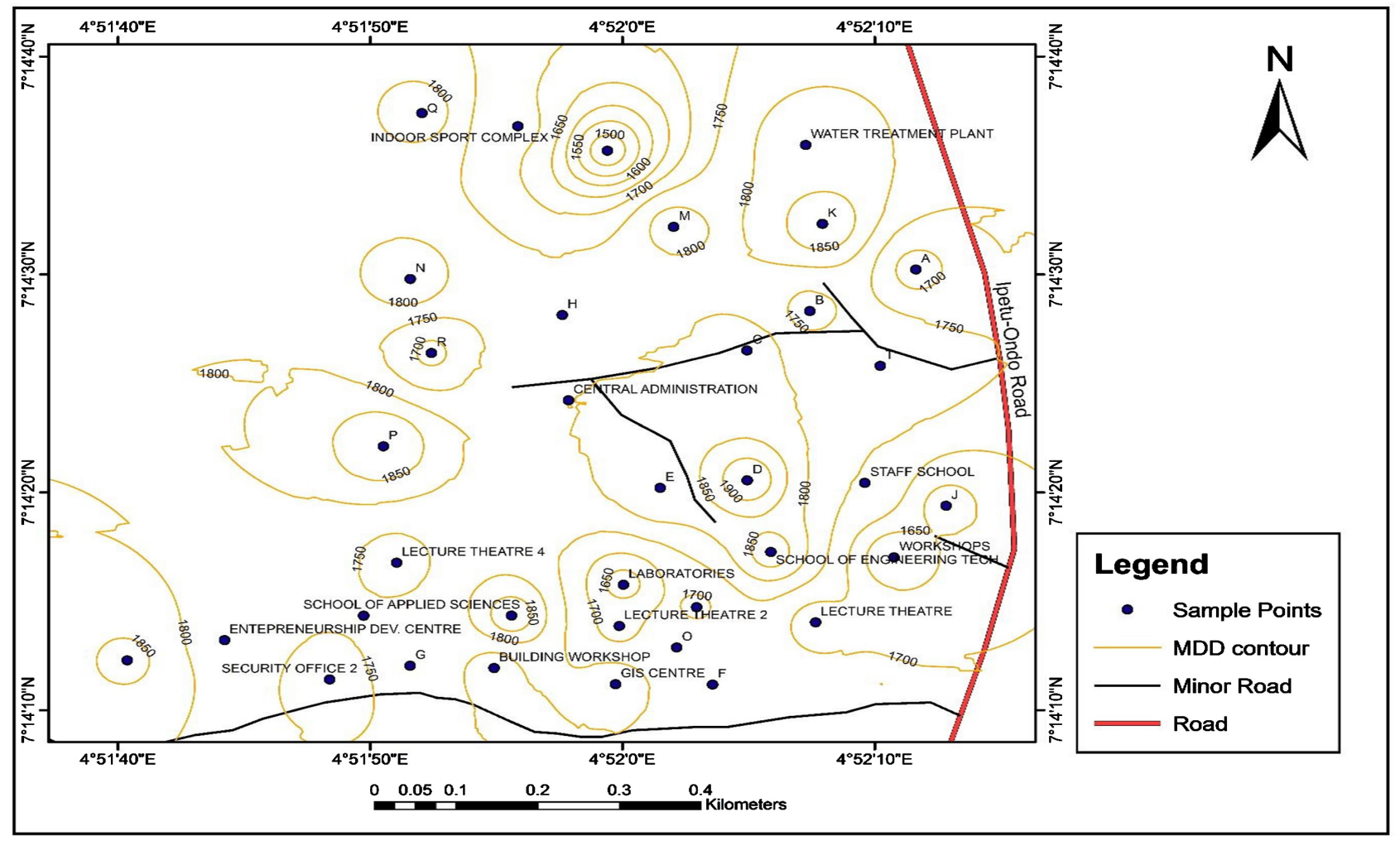

Figure 23. Maximum dry density.

MDD value of $1700 \mathrm{Kgm}^{-3}$ joins areas around Staff School, Lecture Theatres 1 and 2, Contour lines with MDD value of $1750 \mathrm{Kgm}^{-3}$ joins areas around Lecture Theatre 4, MDD of $1800 \mathrm{Kgm}^{-3}$ joins areas around the Indoor Sport Complex, Entrepreneurship Developmental Centre, Building Workshop, Water Treatment Plant, Central Administration, $1850 \mathrm{Kgm}^{-3}$ MDD joins areas around the School of Business and Management Studies, School of Engineering Technology, while the highest MDD of $1900 \mathrm{Kgm}^{-3}$ joins areas around the School of Applied Science. From the Thematic map (Figure 24), areas with the same colour pattern have the same range of Maximum dry density

\subsection{Elevation}

Figure 25 presents the elevation of the study area. It can be seen that the highest point within the study area is around Lecture Theatre 4 with an elevation of $266 \mathrm{~m}$ above mean sea level, while the lowest point within the study area is around the Indoor Sport Complex with an elevation of $234 \mathrm{~m}$ above mean sea level, knowing the highest elevation in the area gives a good location for citing water treatment plant and reservoir whereby treated water can be easily channeled in pipes through gravity.

\subsection{Soil Classification}

The results obtained under the AASHTO classification system are shown in Figure 26. The categories of soil in the study region are A-2-4, A-2-5, A-2-7, 


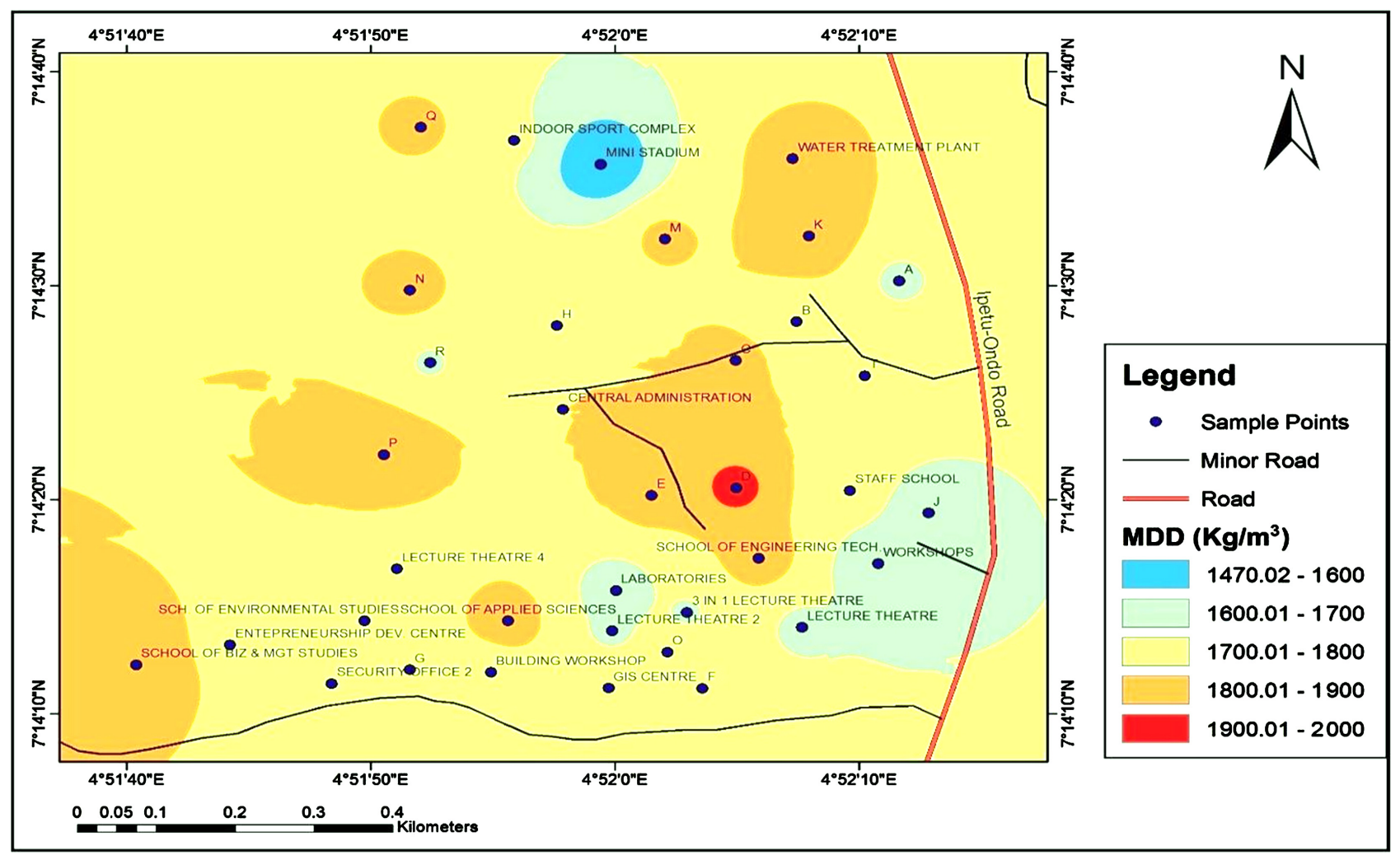

Figure 24. Thematic map of maximum dry density.

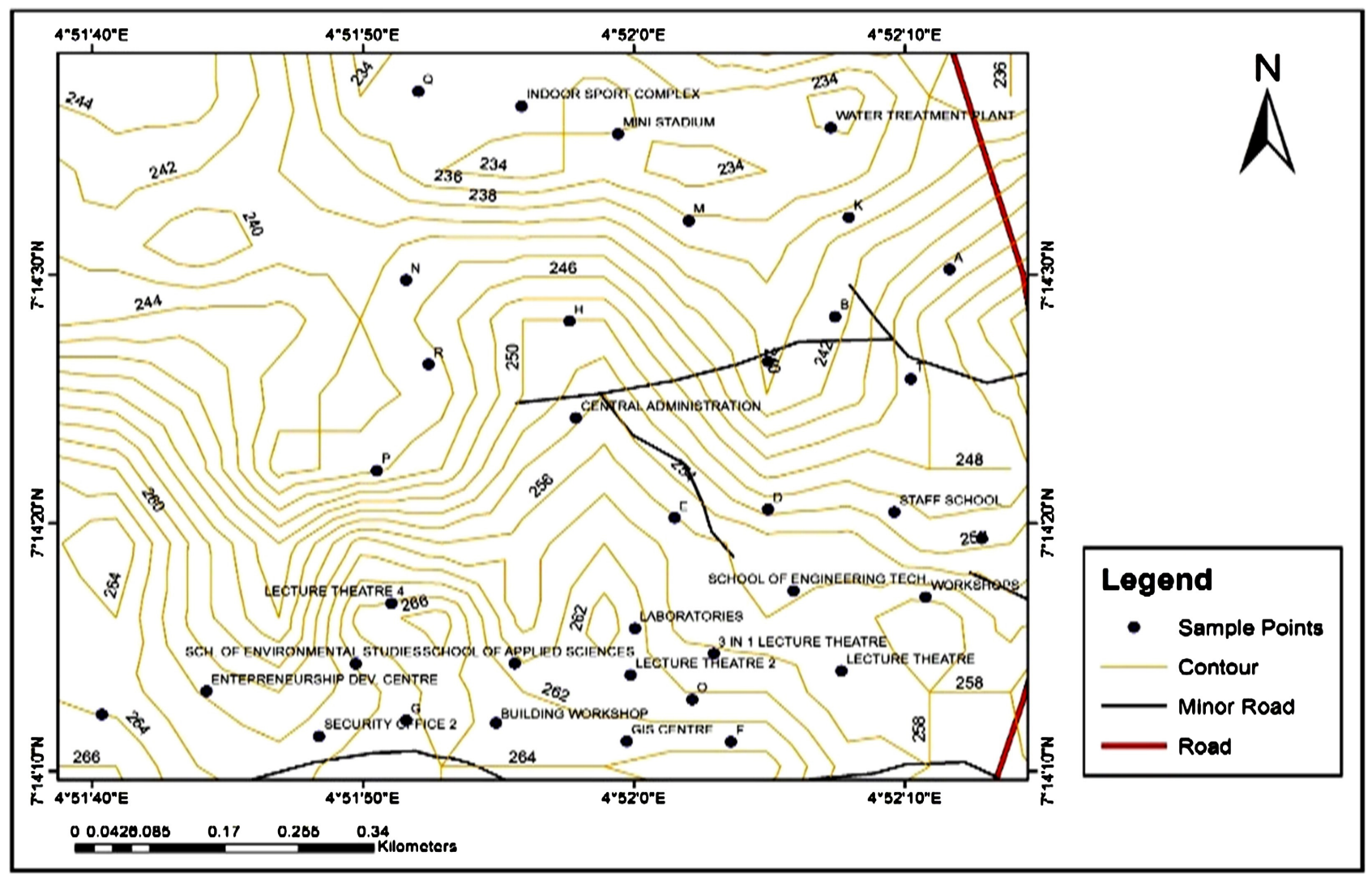

Figure 25. Elevation. 


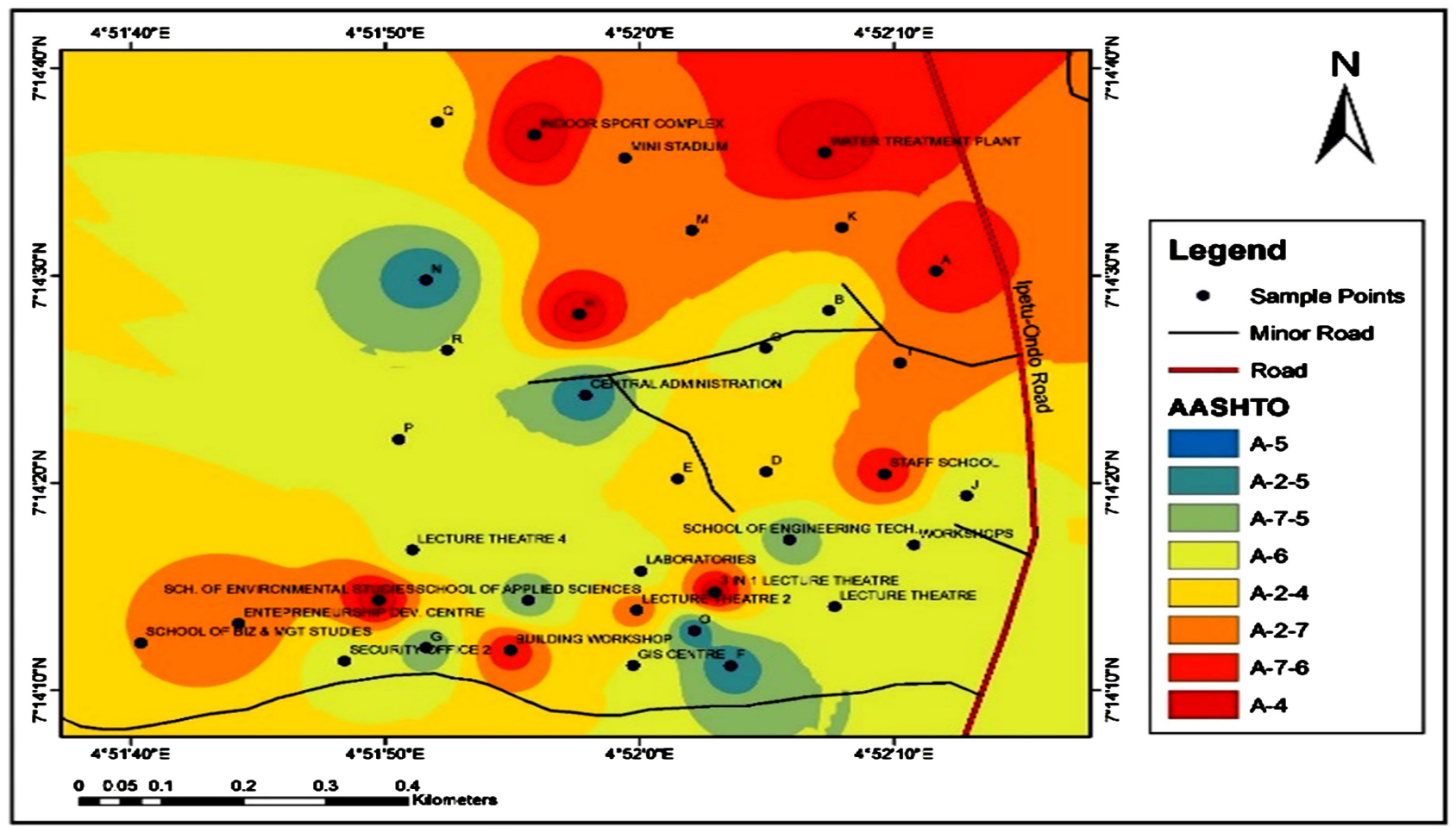

Figure 26. Soil classification.

A-4, A-5, A-6, A-7-5, and A-7-6. The classification of soil around School of business and management studies and Mini stadium is A-2-4, A-2-5 soil can be found around School of Engineering Technology, School of Applied Sciences, these are very suitable as subgrade materials. A-2-7 soil, a good performance soil can be found around Lecture theatre 2 and Entrepreneurship and Development Centre, A-4 soil can be found in location Indoor Sport Complex, Lecture Theatre 1 and 2, School of Environmental Studies, and Water Treatment Plant, A-5 soil can be found around Central Administration. The soils in these aforementioned locations are good for subgrade material. While A-6 soil can be found around the GIS Centre. A-7-5 soil can be found around Lecture Theatre 4, Laboratories, Workshops, Security office, A-7-6 soil can be found around Staff school and the Building Workshop area. The soils present at these locations are not suitable as subgrade materials. The most predominant soil class is the A-7-5 and the less predominant class is A-7-6, and A-6.

\section{Conclusions}

From the study, the following conclusions were drawn:

- The highest natural moisture content can be found in location $M$ and the lowest natural moisture can be found in the School of Engineering Technology.

- The highest liquid limit value can be found in the Workshop area and the lowest liquid limit value can be found in the Water treatment plant area.

- The highest plastic limit value can be found in location $\mathrm{O}$ and the lowest 
plastic limit value can be found in the Water treatment plant area.

- The highest plasticity index of soil was found in the Workshop area, and the lowest plasticity index can be found around locations $\mathrm{K}, \mathrm{D}, \mathrm{N}, \mathrm{O}$ and the water treatment plant area

- The highest percentage fine can be found in Workshop area and the lowest percentage fine can be found in School of Engineering Technology.

- The highest percentage of sand can be found in the Water treatment plant area and the lowest percentage of sand can be found in the School of Applied Sciences area.

- The highest percentage gravel is present in Water treatment plant area and the lowest percentage gravel is found in location $\mathrm{F}$.

- The highest specific gravity of soil is present in the Lecture theatre area and the lowest specific gravity is present in location $\mathrm{M}$.

- The highest optimum moisture content can be found in building workshop and the lowest moisture content can be found in location P.

- The highest maximum dry density is present in location $\mathrm{D}$ and the lowest is found in the mini stadium.

- The most predominant soil class is the A-7-5 and the less predominant class is A-7-6, and A-6.

\section{Conflicts of Interest}

The authors declare no conflicts of interest regarding the publication of this paper.

\section{References}

[1] Ferkete, A.Y. (2012) Remote Sensing and Geotechnical Investigations of Expansive Soils. Doctoral Thesis, University of Twente, Enschede.

[2] Ramamurthy, T.N. and Sitharam, T.G. (2005) Geotechnical Engineering [Soil Mechanics]. S. Chand.

[3] NRCS (2011) Utilising GIS in the Soil Survey.

[4] Amardeep, S., Shahid, N., Chitra, R., Manish, G. and Vel, N.K. (2015) GIS Applications in Geotechnical Engineering. International Journal of Latest Trend in Engineering and Technology, 5, 36-42.

[5] Adams, T.M. and Bosscher, P.J. (1995). Integration of GIS and Knowledge-Based Systems for Subsurface Characterization. In: Maher, M.L. and Tommelein, I., Eds., Expert Systems for Civil Engineers. Integrated \& Distributed Systems, ASCE, New York.

[6] Lefchik, P.E, Thomas, E. and Kirk, B. (2006) Development of National Geotechnical Management System Standards for Transportation Applications. GEOCongress. Geotechnical Engineering in the Information Technology Age, Atlanta, GA, 26 February-1 March 2006, 1-6.

[7] Aderinola, O.S., Akingbomire, S.L. and Quadri, A.I. (2017) Geographic Information System GIS as a Search Tool for Geotechnical Information of Soil. International Journal of Scientific and Engineering Research, 8, 1-9. 